Review

\title{
Agrivoltaics: A Climate-Smart Agriculture Approach for Indian Farmers
}

\author{
Rakeshkumar Mahto ${ }^{1, *(\mathbb{D}}$, Deepak Sharma ${ }^{2}$, Reshma John ${ }^{1}$ and Chandrasekhar Putcha ${ }^{2}$ \\ 1 Computer Engineering Program, California State University, Fullerton, CA 92831, USA; rsj@csu.fullerton.edu \\ 2 Department of Civil and Environmental Engineering, California State University, Fullerton, CA 92831, USA; \\ dsharma@fullerton.edu (D.S.); cputcha@fullerton.edu (C.P.) \\ * Correspondence: ramahto@fullerton.edu
}

check for updates

Citation: Mahto, R.; Sharma, D.; John, R.; Putcha, C. Agrivoltaics: A Climate-Smart Agriculture Approach for Indian Farmers. Land 2021, 10, 1277. https://doi.org/10.3390/ land10111277

Academic Editors: Mária

Szalmáné Csete and Monica Salvia

Received: 26 October 2021

Accepted: 16 November 2021

Published: 20 November 2021

Publisher's Note: MDPI stays neutral with regard to jurisdictional claims in published maps and institutional affiliations.

Copyright: (c) 2021 by the authors. Licensee MDPI, Basel, Switzerland. This article is an open access article distributed under the terms and conditions of the Creative Commons Attribution (CC BY) license (https:// creativecommons.org/licenses/by/ $4.0 /)$.

\begin{abstract}
India is a leader when it comes to agriculture. A significant part of the country's population depends on agriculture for livelihood. However, many of them face challenges due to using unreliable farming techniques. Sometimes the challenges increase to the extent that they commit suicide. Besides, India is highly populated, and its population is steadily increasing, requiring its government to grow its GDP and increase its energy supply proportionately. This paper reviews integrating solar farming with agriculture, known as Agrivoltaics, as a Climate-Smart Agriculture (CSA) option for Indian farmers. This study is further supported by the Strength, Weaknesses, Opportunities, and Threats (SWOT) analysis of agrivoltaics. Using the SWOT analysis, this article presents how agrivoltaics can make agriculture sustainable and reliable. This paper identifies rural electrification, water conservation, yield improvement, sustainable income generation, and reduction in the usage of pesticides as the strengths of agrivoltaics. Similarly, the paper presents weaknesses, opportunities, and threats to agrivoltaics in India. The research concludes with the findings that agrivoltaics have the potential of meeting multiple objectives such as meeting global commitments, offering employment, providing economic stability, increasing clean energy production capacity, conserving natural resources, and succeeding in several others. The paper also includes a discussion about the findings, suggestions, and implications of adopting agrivoltaics on a large scale in India.
\end{abstract}

Keywords: SWOT analysis; solar energy; sustainable income; Paris Climate Agreement (PCA); agriculture; greenhouse gas (GHG); carbon dioxide $\left(\mathrm{CO}_{2}\right)$; climate-smart agriculture (CSA)

\section{Introduction}

Technology advancements are creating awareness about the long- and short-term impacts of climate change on humans. Simultaneously, as the global population is increasing, there is a continuous increase in energy demand. Clean and alternative energy generation is emerging as a solution to the global energy demands. Many new initiatives aimed at reducing the dependence on fossil fuel-based energy sources were taken up by participating countries with the signing of the Paris Climate Agreement (PCA) in 2015 [1]. The agreement bound 196 member nations to take adequate measures to reduce Greenhouse Gas (GHG) emissions and increase renewable energy generation [2]. This initiative led member countries to increase their investment in generating renewable energy [3].

The core strategy adopted to meet the PCA goals has been to replace traditional power generation sources such as coal, gas, and nuclear energy with renewable energy alternatives, including solar, wind, geothermal, biomass, tidal, and other methods [4]. While these alternatives offer compliance, adopting them raised many challenges. The majority of these alternatives are perceived as costly. Hence, to address these concerns, the COP26 held in Glasgow in 2021 pledged to provide $\$ 100$ billion per year to developing nations [5]. These financial resources will give the developing countries equitable opportunities to adopt newer technologies to mitigate the ill effects of climate change. Furthermore, the rapid technological advancements reduce costs, but as the alternatives are used on mass 
levels, the widespread acceptance will also drive down costs $[3,6]$. Another challenge in their adoption is their installation. However, according to Arantegui et al., solar- and wind-powered energy generation alternatives are convenient as these can be deployed in modular forms [5]. Hence, the two choices are more popular compared to other renewable energy alternatives.

Even after the tall commitment made by the member nations at PCA, a week before the COP26 conference, countries responsible for 55\% of GHG emissions submitted nationally determined contributions and long-term strategies [7]. At the COP26 meeting, it was observed that the nationally determined contributions by PCA signatories were not adequate to reduce the impact of GHG on global warming and safeguard health [8]. Thus, it will eventually increase the projected global temperature by $2-7^{\circ} \mathrm{C}$ by the end of this century.

Similar concerns were raised at the Intergovernmental Panel on Climate Change (IPCC). The IPCC's Sixth Assessment Report's Summary for Policymakers warns about significant variations in climate. As per the report, with a high confidence level, it is expected that regions are going to face extreme heat affecting the agriculture sector [6]. Therefore, the major GHG contributing countries need to take expeditious steps to reduce their emissions.

GHG gases include Carbon Dioxide $\left(\mathrm{CO}_{2}\right)$, Methane $\left(\mathrm{CH}_{4}\right)$, Nitrous Oxide $\left(\mathrm{N}_{2} \mathrm{O}\right)$, and fluorinated gases. In 2019, $\mathrm{CO}_{2}$ accounted for $65 \%$ of global GHG emissions [8] and $80 \%$ of US GHG emissions [8]. These statistics convey that $\mathrm{CO}_{2}$ represents a significant share of GHG emissions. According to Ritchie et al., India's per capita $\mathrm{CO}_{2}$ emission by the average person is around 1.84 tons for 2019, which is around $25 \%$ of the world's per capita emission [9].

The same survey highlighted that the annual $\mathrm{CO}_{2}$ emission from India was around 2.6 million tons in the year 2019, when the total $\mathrm{CO}_{2}$ emission for the world was 36.44 million tons. Besides, it was also found that India was the third-largest contributor to GHG gases worldwide [9]. As per IPCC's Technical Summary published in 2021, the Indian Ocean region is heating up rapidly. The report's authors have expressed very high confidence about the heating-up issue [10], and India should prepare itself for the impending challenge.

From a slightly different perspective, since India is highly populated, and the numbers are steadily increasing, its government must grow its GDP and increase its energy supply proportionately. However, the increase in GDP and energy would come at a cost. It is estimated that a $1.308 \%$ increase in economic growth will result in a $1 \%$ increase in $\mathrm{CO}_{2}$ emission for low-income countries such as India [11]. All these facts call for adopting greener and sustainable alternatives to be able to deal with higher heat by increasing dependence on sustainable technology

According to [12], major sources of GHG emissions are the energy and agriculture sectors, as shown in Figure 1. Similarly, studies also pointed towards transportation as one of the significant sources of $\mathrm{CO}_{2}$ emissions. Even with technologies such as electric cars at the helm, it is estimated that by 2050, the $\mathrm{CO}_{2}$ emissions from the transportation sector will be around 1092 million tons [13]. It is worth noting that the $\mathrm{CO}_{2}$ emissions from transportation add up to $10 \%$ of the total GHG emissions [13]. Transportation is deeply ingrained in people's lives and is a very well-researched area. The other areas, though significant, are often ignored. Hence, to manage the dual issue of achieving a higher GDP and reducing GHG emissions, it is rational for India to adopt renewable energy alternatives in agriculture that affect the mass population and can be widely effective in emission reduction and growth. 


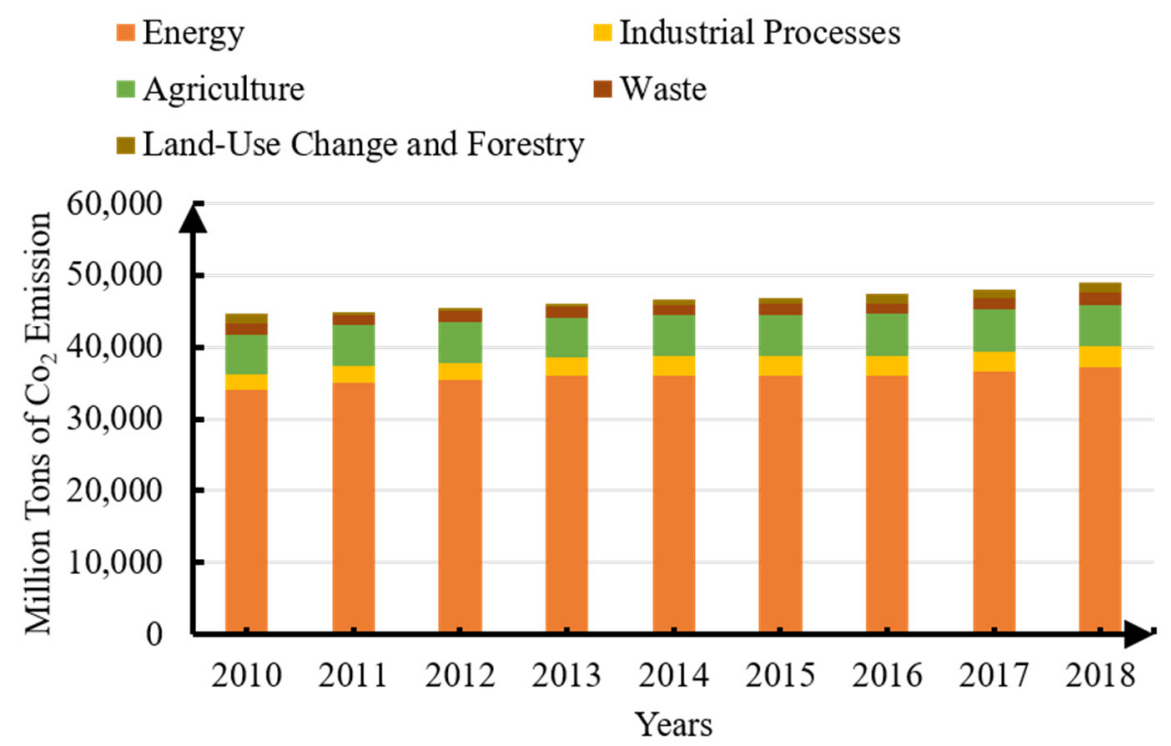

Figure 1. Sector wise contribution to GHG emissions from 2010 to 2018 Data Source: World Resource Institute.

Agriculture is considered to be the backbone of the Indian economy. As per the last census conducted in $2011,70 \%$ of its population was employed in agriculture [14]. About $47 \%$ of the workforce was directly involved with farm-related occupations as per a survey conducted by the country's Labor Bureau in 2015-2016 [14]. Even with such prominent workforce numbers in Indian agriculture, its contribution to the country's GDP is merely around $17 \%[14,15]$. The vast expanse of the agriculture sector in the country and its contribution to GDP result in 18\% of the country's GHG emissions. This is primarily due to the usage of outdated and unreliable farming techniques [16]. Moreover, excess utilization of government-subsidized fertilizers and pesticides resulted in the degradation of the farmland. According to the IPCC report published in 2019, land degradation is a driving force of climate change by increasing GHG emissions and lowering carbon uptake rates [17]. Hence, self-sustained and growth-driven agriculture is essential for India to achieve a higher growth rate and provide employment to its growing population $[16,18,19]$.

It is imperative to develop innovative solutions for a densely populated country such as India to meet multiple objectives such as PCA commitments, employment, and food security. This research work seeks to present one such alternative that addresses all the above objectives. Specifically, this paper presents the integration of solar farming with traditional farming, which leads to meeting all the objectives envisioned in Climate-Smart Agriculture (CSA).

The CSA aims to achieve three main objectives. The first objective is to increase the productivity of agriculture that translates to an increase in farmers' income, provides food security, and ensures the overall development of the rural economy [20,21]. The second objective of CSA is to make the farm yield less vulnerable to the aberrations such as natural disasters, pests, diseases, and others [20,21]. Lastly, the final objective is to reduce GHG emissions by developing technologies that can be used in agriculture $[20,21]$. In the past, many research articles pertaining to solar energy with agriculture specific to India were published, presenting multiple applications where their usage can create CSA. Authors in $[22,23]$ explored a solar-powered irrigation system for sustainable agriculture for India. Similarly, a solar-energy-powered crop and graining dying facility were proposed for Rajasthan [24]. The same study highlighted solar energy for air and water heating for dairy operations [24]. Additionally, a sun-powered system was used to obtain potable water and sewage treatment in arsenic-affected rural areas in the Kaudikasa village in India [25]. These examples demonstrate the use of solar panels for supporting activities that help agriculture, but India also used solar energy systems for enhancing agriculture itself. 
A number of projects were described in a report by the Indo-German Energy Forum Support Office (IGEF-SO) and the National Solar Energy Federation of India (NSEFI) [26]. The aim of this report was to present a comprehensive overview of projects that used solar energy with agriculture in India [26]. According to this report, 13 operational solar projects on agriculture plots have been functional since January 2021, collectively generating 48.4 MW of electricity [26]. The effect of shade of $100 \mathrm{KW}$ capacity solar panels on crop yield was presented in a research paper focusing on Jodhpur, Rajasthan [27]. Similarly, research was conducted to investigate the effectiveness of similar systems on grape cultivation [28]. In this research, Malu et al. also concluded that if similar solar systems are utilized across India, they can generate 16,000 GWh of electricity [28]. Another study was conducted on a grid-tied system of MW production capacity in Charanka Solar Park at Gujarat [29]. The study found that the utilization of solar panels in farmland resulted in converting salt marshy barren land into fertile land, ideal for cultivating tomatoes [29]. The system also enabled exporting 1.68 million kWh of electricity to the Gujarat Energy Transmission Corporation (GETCO) grid [29]. Besides the studies focusing on India, agrivoltaics were researched and adopted in many countries worldwide, namely Italy, China, France, Germany, the US, and several others [30].

In continuation to the research conducted about solar system applications in India, this paper presents a SWOT analysis of having an embedded solar panel in agricultural land. This approach is known as Agrivoltaics, and it has the potential to offer multiple benefits. Some of the benefits include increasing revenue, providing rural electrification, reducing water usage for irrigation, and lowering GHG emissions [31]. A detailed SWOT analysis is necessary for understanding the future viability of agrivoltaics in a resource-constrained country such as India [32]. A similar SWOT analysis was conducted for the agriculture sector of France aimed at maximizing land utilization and optimizing crop yield [33]. Moreover, since the technology adoption in India's agriculture is much slower than in any other developing country [34], a detailed SWOT analysis will be helpful. The theoretical background discussing the need to switch to agrivoltaics in the Indian context is presented in Section 2. Section 3 explains the methodology used for the SWOT analysis. The following section covers the core of this paper, covering the SWOT analysis of agrivoltaics. The final section includes a discussion about the findings, suggestions, and implications of adopting agrivoltaics on a large scale in India.

\section{Theoretical Background}

Before going over the SWOT analysis, it is essential to understand the background regarding agrivoltaics. This section will elaborate on the current state of solar energy production and agriculture in India. Before any SWOT analysis, it is essential to "examine the business, industry, and market situation" [35]. This approach is demonstrated in this section which became the basis of conducting an in-depth SWOT analysis.

\subsection{Solar Farming Potential in India}

The power sector majorly contributes to the GDP growth of a country. The Government of India (GOI) is serious about its power sector growth which is evident from the fact that India's rank improved from 137 in the year 2014 to 115 in the year 2019 due to an improvement in electricity reliability [36]. The total electricity production in India was 374.65 GW in December 2020, which is the third-largest in the world, as shown in Figure 2a [37]. The electricity production by lignite-based power generation (approximately 6.7 GW) from 2018 to 2020 is included with coal in Figure 2a. The other part of this figure, Figure 2b, shows a steady increase in Renewable Energy Sources (RES) in overall electricity production [37]. However, the electricity production from coal-based power plants also increased during the same duration, as shown in Figure 2a. Additionally, the coal-based power plant's contribution to electricity generation in 2020 was around $53 \%$. For reducing GHG emissions, it is essential to reduce the dependence on coal-based power 
plants. The targeted reductions can be achieved by increasing the use of renewable energy such as solar energy.

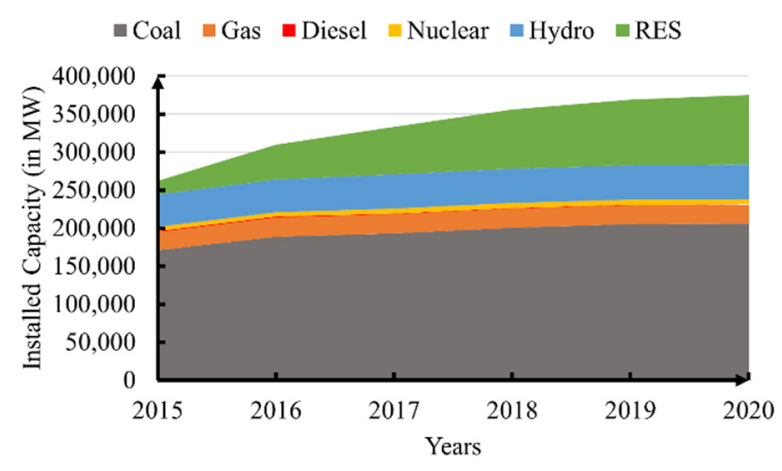

(a)

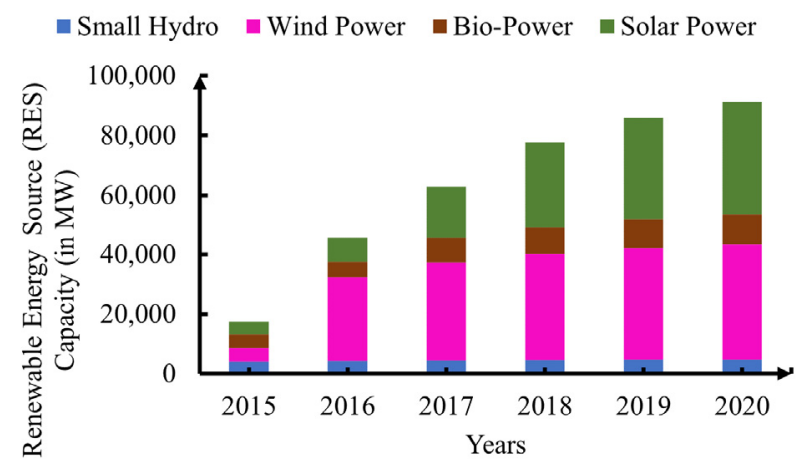

(b)

Figure 2. Annual electricity-generation-installed capacity reported by Power Ministry, India: (a) Electricity-generationinstalled-capacity from all sources. (b) Breakdown of power generation by the different renewable energy sources.

According to the research [38], around $83.4 \%$ and $81.33 \%$ of the total landmass in India is suitable for solar- and wind-based energy generation, respectively. The installation of wind-based power generation is challenging because of issues such as the need for open space, wake effect, topographic impact, and annual wind intensity [39]. Hence, they may not be ideal for use at many farmlands across the country. On the contrary, solar panels make them suitable for power generation from rooftops, building facades, farmlands, roadsides, and other places that are open to the sky. As per Kar et al., India receives solar irradiation sufficient to produce $500,000 \mathrm{TWh}$ per year [40]. The production is calculated considering only $10 \%$ of the energy conversion. The energy production is bound to increase from the advancements in solar manufacturing processes and improvements in the Maximum Power Point Tracker (MPPT). The solar energy potential across India estimated by the National Institute of Solar Energy (NISE) is shown in Figure 3 [41].

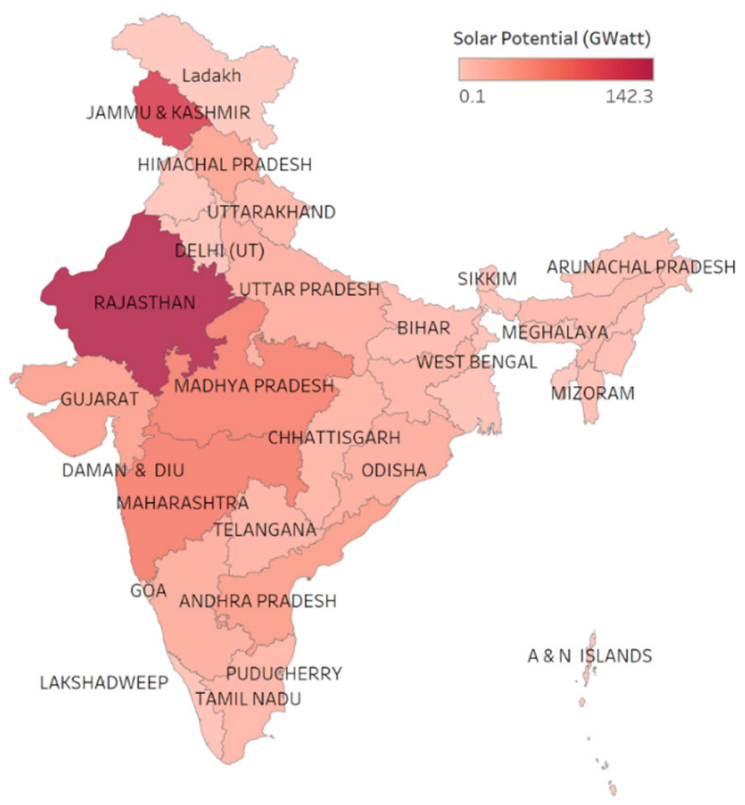

Figure 3. Countrywide electricity generation potential as per the National Institute of Solar Energy (NISE). 
For India to achieve higher electricity production through solar energy requires the deployment of solar systems throughout the country. However, according to [42], India had 140 million hectares of cultivated land in 2016, translating to around $42.5 \%$ of its total landmass. The vast landmass in the form of cultivable land could be low-hanging fruit for implementing solar energy harvesting. However, the owners of the farmlands are currently unaware of the potential benefits of solar systems and are not interested in installing them [43,44]. On the other hand, other non-farming stakeholders interested in harvesting solar system benefits face a legal bottleneck in getting access to such [43,44]. The Land Acquisition Bill Amendment introduced by the Indian Parliament in 2015 made it impossible for non-farming private enterprises to acquire agricultural land [45]. Thus, it is challenging to incubate the idea of increasing solar-based electricity generation in the rural parts of India.

\subsection{Distress in Farmers}

India is the second-largest population facing many ecological and economic challenges [46-48]. For the country to prosper and provide for its growing population, fruits of development must reach India's rural parts. The agricultural sector employs a significant population but contributes to one-fifth of the GDP [49]. Due to poverty and a lack of awareness, farming is still conducted using conventional techniques in India. The hardships farmers face are the biggest hurdle in switching to high-yield technologies [50,51]. The challenges created inertia among the farming community to stick to conventional methods and forced them to take extreme steps.

According to the National Crime Reporting Bureau (NCRB) data in 2019 [52], the suicide rate in farmers is disturbingly high, as shown in Figure 4. In the last decade alone, 15,000 farmers committed suicide every year on average, which translates to 48 farmers committing suicide every single day. According to survey results published in the Proceedings of the National Academy of Sciences (PNAS), 335 Indian farmers commit suicide with every $5{ }^{\circ} \mathrm{C}$ increase in temperature [53]. The statistics of suicide in states where the numbers are troublesome are represented in Figure 5 [52]. The data used to develop Figure 5 include people who are directly and indirectly associated with agriculture.

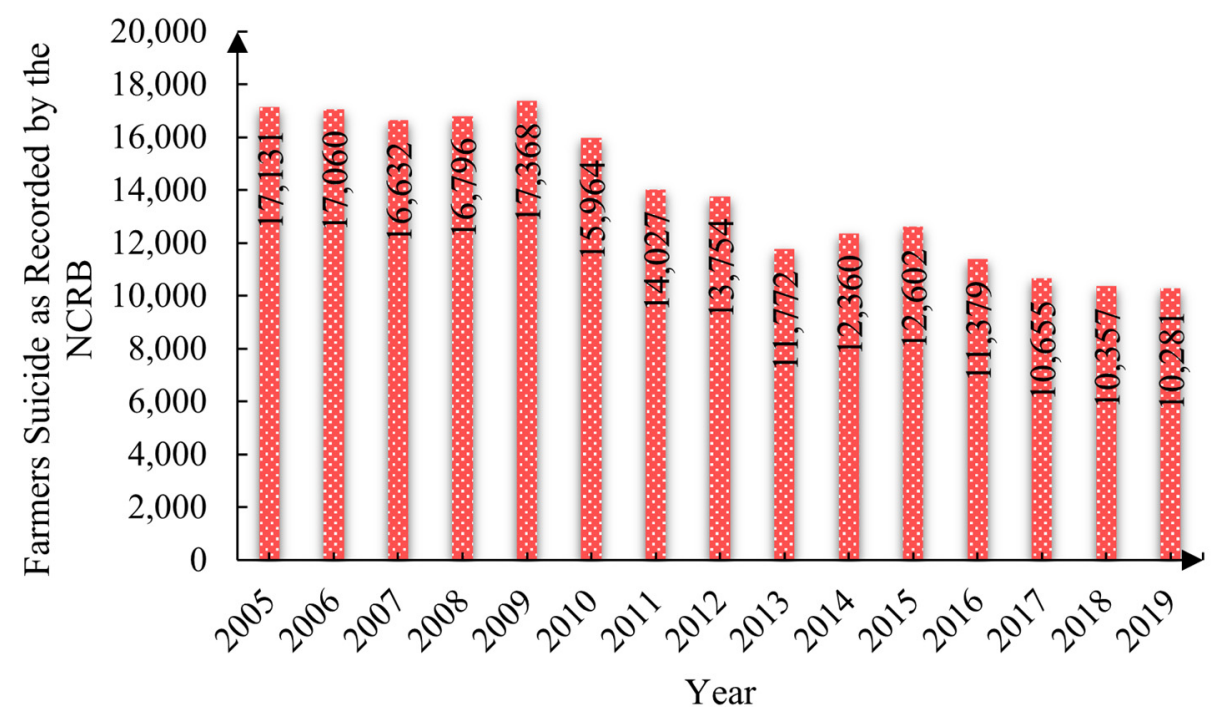

Figure 4. Farmer suicides from 2005 to 2019 according to NCRB data. 


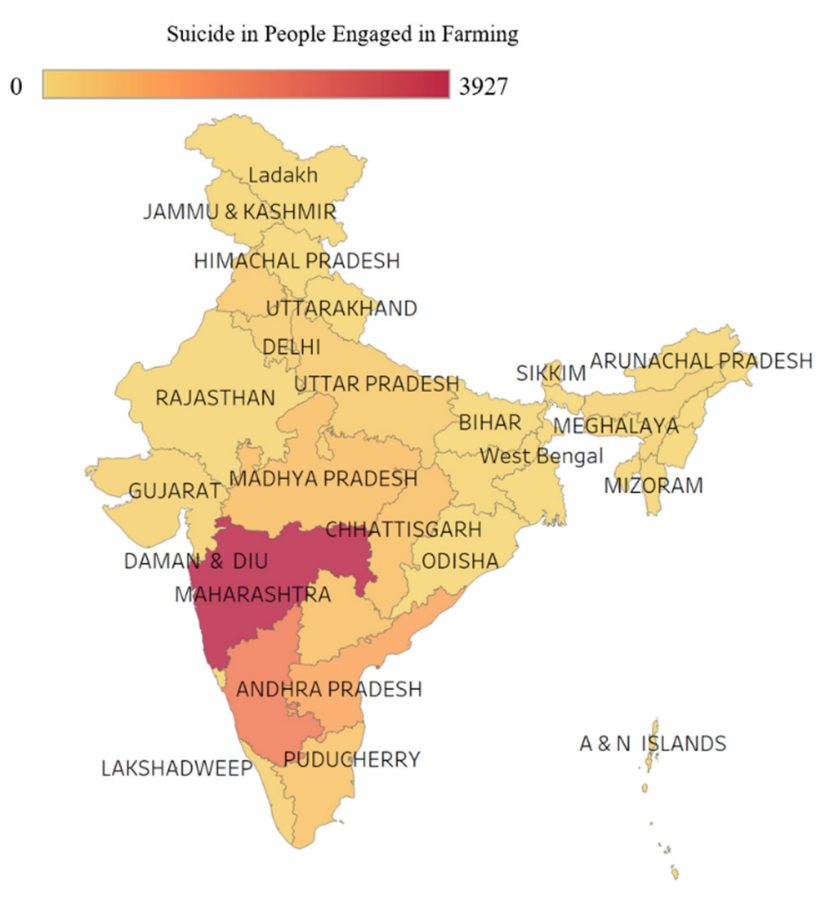

(a)
Suicide in People Engaged in Farming Sector

0

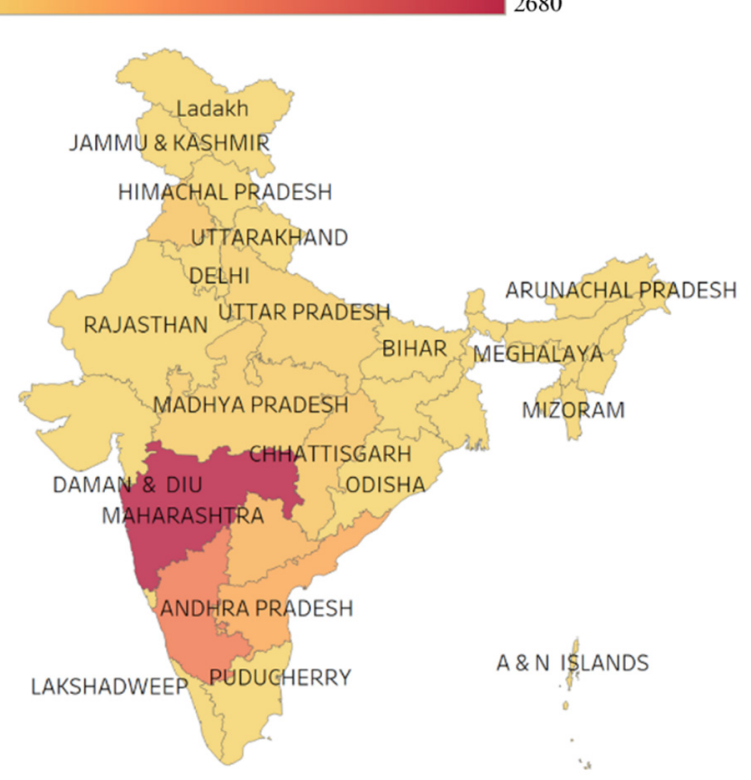

(b)

Figure 5. Number of suicides committed in the year 2019 as per NCRB by the (a) farmers, (b) persons engaged in farming related sectors.

The NCRB identified many factors responsible for farmers' high suicide rate, including farming-related issues, indebtedness or bankruptcy, family problems, drug abuse/alcoholic addiction, and many more [52], as shown in Figure 6. Bankruptcy or indebtedness and poverty were the primary reasons for the farmers' suicide, as shown in Figure 6 [52]. Farming is a demanding profession since farmers need to wait for almost half a year or more to get a return on their investments.

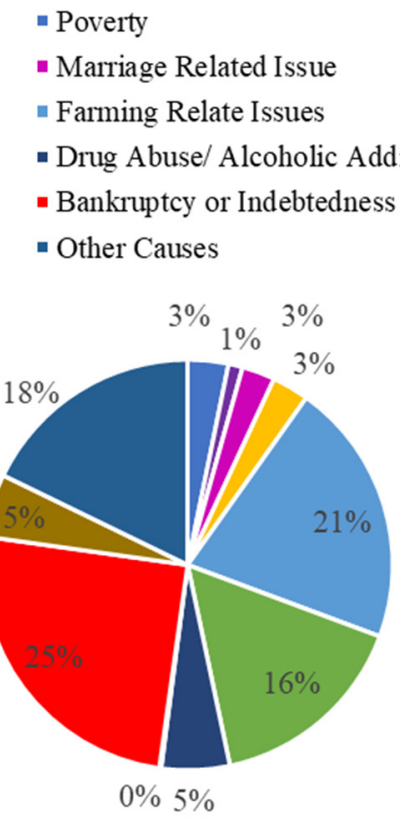

2014

\author{
- Property Dispute \\ " Family Problems \\ - Illness \\ - Fall in Social Reputation \\ - Causes Not Known
}

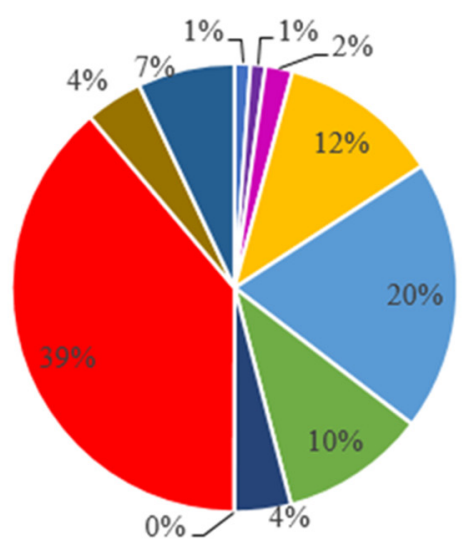

2015

Figure 6. Causes of farmers' suicide identified by NCRB in the year 2014 and 2015. 
Many uncertainties can hurt farmers' investment during land preparation, the sowing of seeds, crop growth, and harvesting processes. All such uncertainties make agriculture an unreliable source of income. An unpredictable income from agriculture has resulted in rural youth migrating to the urban parts of India [54]. This further increased the burden on the urban systems such as transportation, built environment, electricity, and others. Such migrations will increase associated problems such as increased congestion, GHG gas emissions, and many others. Therefore, it is in the country's best interest to make farming profitable and reliable, which can be achieved by providing opportunities for a secondary source of income that can give the farmers income high enough to meet their daily requirements.

Superimposing Figure 5 on Figure 3 shows an interesting result. States with higher suicide numbers are also found to be ideal for solar farming, as shown in Figure 7. Rajasthan is an outlier in this analysis since it is one of the leading states in India for solar farming potential (represented by a darker green shade) with a significantly lower farmer suicide rate (represented by a circle with a big radius in a reddish shade) in Figure 7.

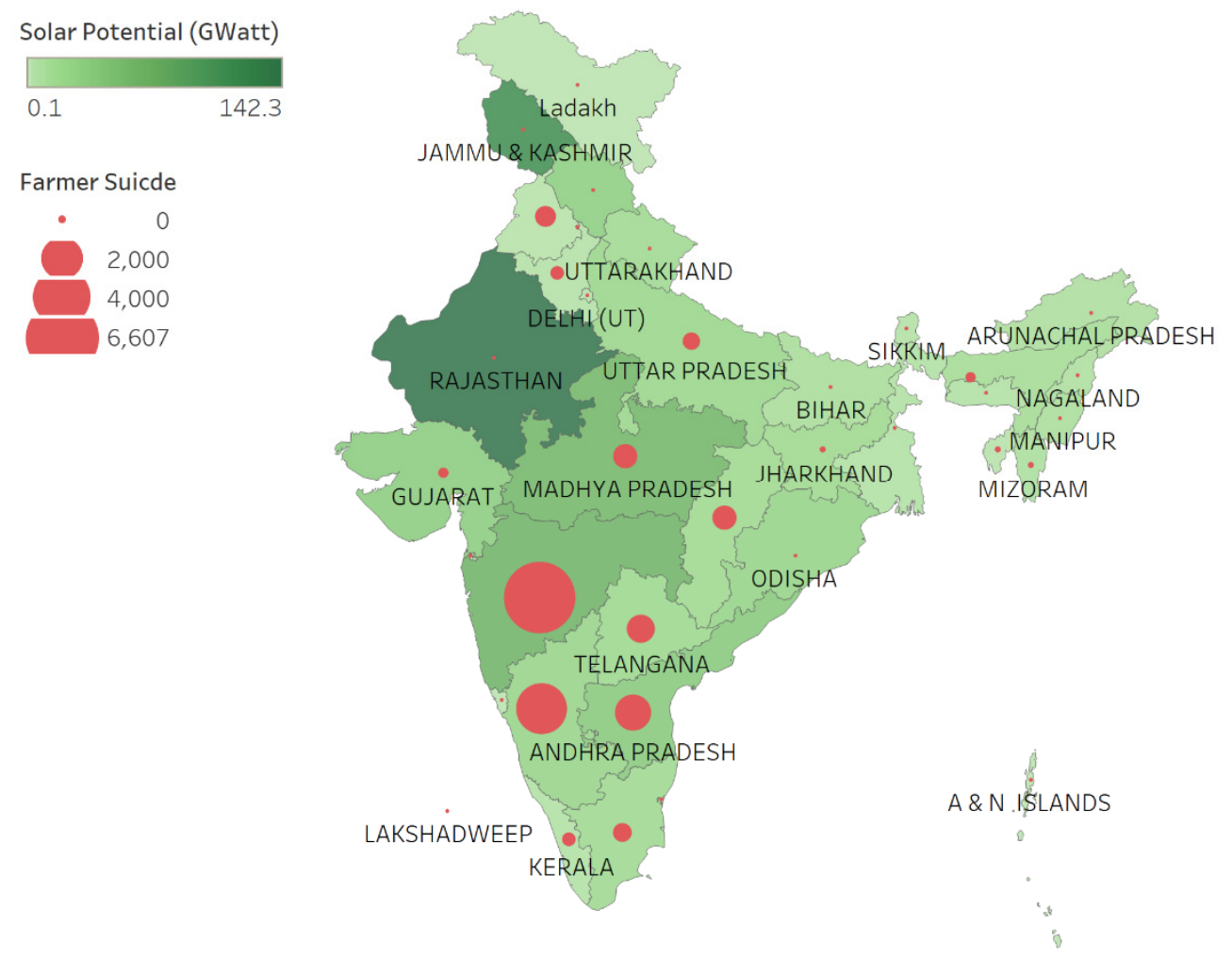

Figure 7. Combining the farmer suicide across India reported in 2019 and solar energy potential estimated by the National Institute of Solar Energy (NISE).

The highly desirable observation (high power generation and low suicide numbers) for the state of Rajasthan is attributed to its landmass consisting of deserts, making it an ideal place for solar power generation. Still, on the other hand, the extreme heat and deserts make it extremely challenging for agriculture. Therefore, farming is scarce in the State of Rajasthan, and thus the farmers' suicide rate is the lowest. On the contrary, Maharashtra and its neighboring states are the worst affected states for farmers' suicide. The solar potential is average, represented by a darker shade (greenish shades), but the suicide numbers are incredibly high, represented by circles with a medium-sized radius (reddish shade). From Figure 7, it is evident that the same states have the highest potential for solar farming.

Over the years, different strategies were presented to address the alarmingly high suicide rate in people employed in the farming sector. In [55], a better loan and credit 
option was presented as a viable solution to reduce farmers' suicide. The same study [55] recommended that a farmer's subsidiary income source can alleviate the farmers' financial distress, which can eventually reduce the farmers' suicide. In this same direction, research aimed to study the efficacy of organic farming on reducing farmer suicide in Tamil Naidu was presented in [56]. The study concluded that organic farming techniques have the potential to reduce the socio-economic problem in small-scale farmers [56]. Similarly, through agrivoltaics, the farmers can earn secondary income and increase the yield on cultivation.

\subsection{Agrivoltaics for Electricity Generation}

The co-location of commercially available solar panels with the agricultural is commonly called Agrivoltaics or Agrovoltaics [57-60]. Agrivoltaics are different compared to typical solar farms since the latter are mainly installed for generating electricity. In agrivoltaics, the solar panels are installed with higher ground clearance for letting the crop grow underneath. Additionally, unlike a typical solar farm where the solar panels are tightly installed to maximize land use, in agrivoltaics, the solar panels are installed with sufficient clearance for easy movement of the farmers and farm equipment, as shown in Figure 8. The solar panels used in agrivoltaics can either have fixed panels or a single-axis or double-axis sun-tracking ability [57]. The double-axis sun tracking is mainly for maximizing the power generation capacity of solar panels. These solar panels are primarily in a grid-tied configuration, such that the excess electricity generated from the system is transferred to the local electricity company's grid [57]. Agrivoltaics are increasingly used around the world due to the multiple benefits $[61,62]$.

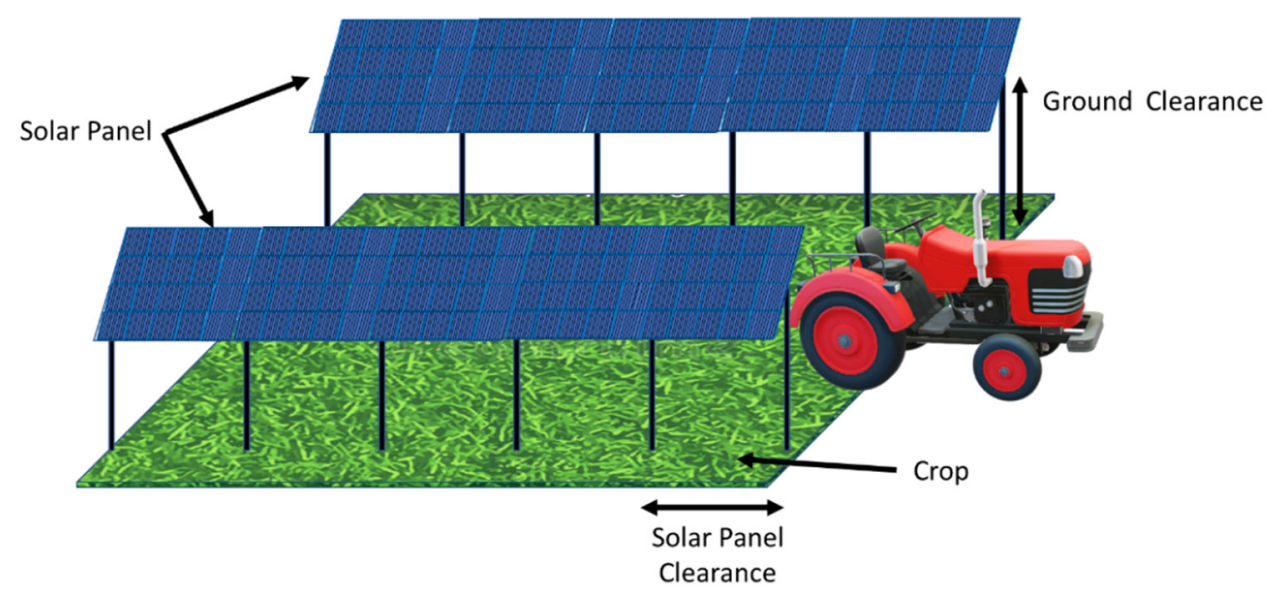

Figure 8. Solar agriculture farm where solar panels are co-located with crops.

\section{Methodology}

Typically, SWOT analysis is conducted to identify the strengths and opportunities for growing an organization such that threats are eliminated by addressing the weaknesses [39]. For determining the strengths, weaknesses, opportunities, and threats, a literature search on keywords such as "solar farming with agriculture", "agrivoltaics", "agrivoltaics", and other words relevant to solar energy with farming was conducted on digital libraries such as IEEE Xplore, Google Scholar, Springer, Elsevier, and Multidisciplinary Digital Publishing Institute (MDPI). Additionally, in this paper, we included reports or news articles of higher reputation. Moreover, we used the snowball technique in identifying other articles relevant to solar farming and agriculture [63]. Additionally, other literature was searched on digital libraries using keywords such as solar farming, agriculture, and policy.

After collecting the relevant literature on the topic, the next step was to classify the literature so that the strengths, weaknesses, opportunities, and threats of solar farming with agriculture could be identified as shown in Figure 9. The literature on similar or derivative research works was selected and analyzed to recognize the strengths of agrivoltaics. The 
opportunity in SWOT analysis is to ascertain the external factors that will improve the prospects of the business model. Hence, in this paper, we identified the factors arising from around the world and policy-related steps taken by local governments which can directly or indirectly impact the overall success of agrivoltaics. Similarly, weakness is studied in SWOT analysis considering the internal factors that might hamper the performance of the concept under the test [64]. Therefore, factors that can hinder the mass adoption of agrivoltaics are shown in Figure 10. Unlike the weaknesses, threats in SWOT analysis are the external factors that can defer or impede a viable goal. A total of 94 articles were identified for the SWOT analysis. The articles where solar energy was used for powering sensors to make agriculture sustainable are not included in this research since they only discuss the limited use of solar-based electricity with agriculture.
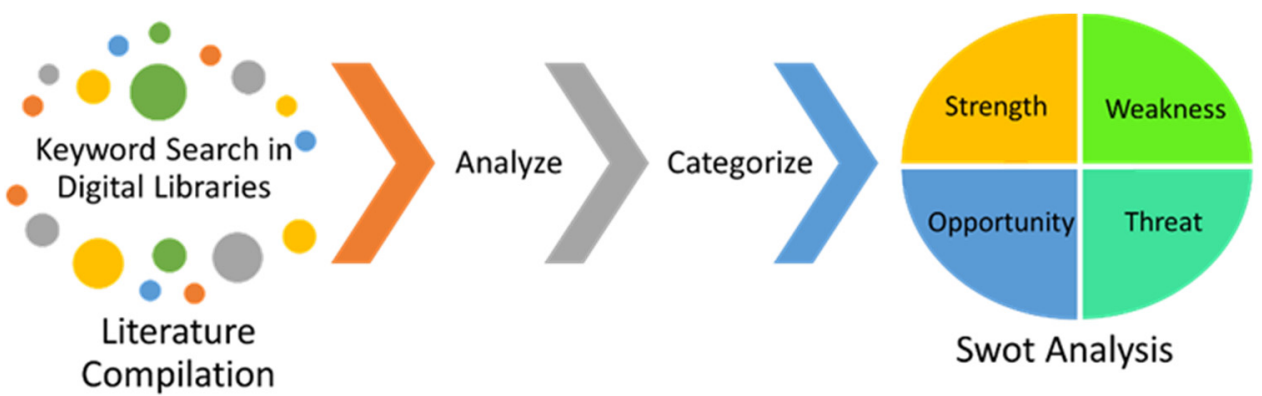

Figure 9. Methodology used for selecting literature for the study and classifying them for the SWOT analysis.

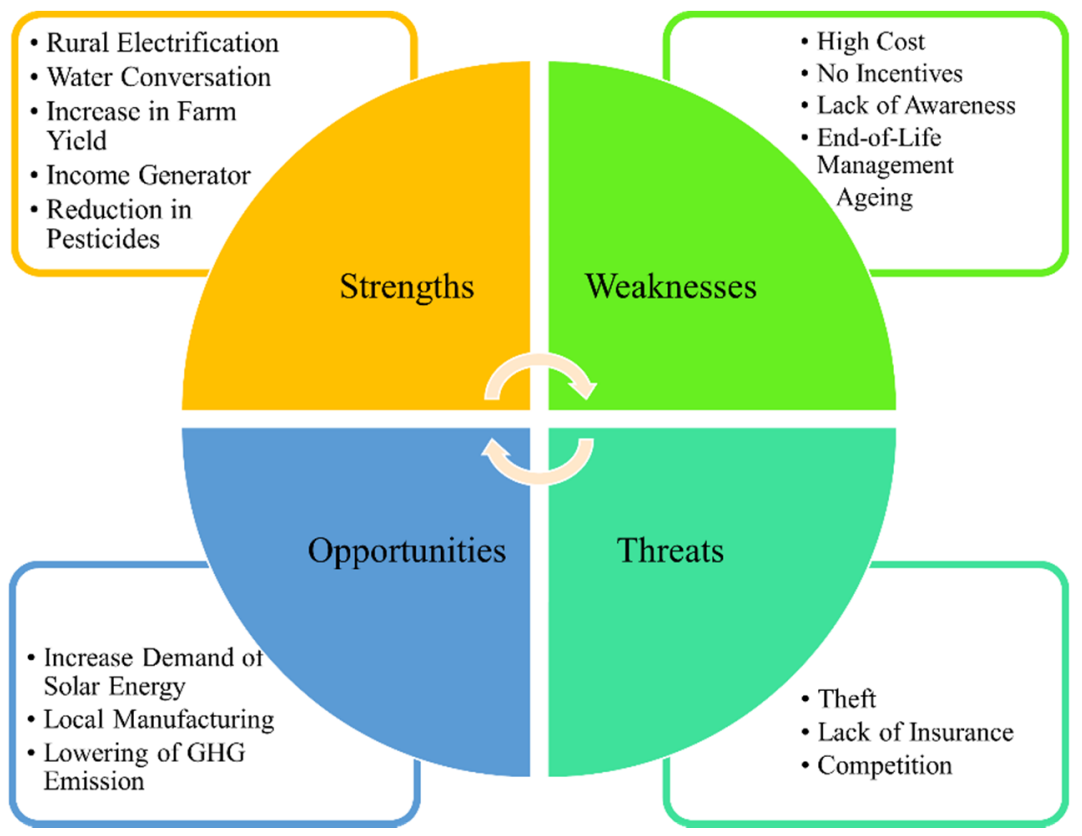

Figure 10. Factors identified in the SWOT (Strength, Weakness, Opportunity, and Threat) analysis.

\section{Results: SWOT Analysis of Solar Farming with Agriculture}

Based on the literature reviews, different factors affecting agrivoltaics in India are classified in various categories in the SWOT analysis, shown in Figure 10.

\subsection{Strengths}

\subsubsection{Rural Electrification}

According to the data released by the World Bank in the past few years, India has progressed significantly in providing access to electricity. The electricity access was $67.6 \%$ in 2011, then reached $97.8 \%$ by 2019 [65]. During the same period, access to electricity in 
rural India also improved significantly, from 56\% in 2011 to $97 \%$ by 2019 [65]. According to a quantitative study conducted in two villages in Andhra Pradesh in India, rural electrification significantly improves the quality of life by providing residents better choices and opportunities to prosper [66]. Similarly, an interview-based survey of more than 10,000 participants across India was conducted to measure the effect of electricity on the quality of life [67]. The study found that getting access to grid-connected electricity caused an increase in the income of rural households by 9\% between 1994 to 2005 [67]. Hence, the rural population must have reliable access to electricity to improve its quality of life. However, many of the barriers to achieving this goal are highlighted in [30]. According to Blankenship et al., obstacles such as the limited power generation capacity of utility companies, corruption, geographical remoteness, and the poor economic condition of residents are a few of the barriers preventing the rural parts of India from having reliable electricity [30]. Though the obstacles exist, lessons can be learned from the way it was tackled across the world.

Many researchers showed the effectiveness of agrivoltaics across different states in India to provide electricity in rural parts of India [28,68-70]. In [28], the effect of colocating agrivoltaics systems with grapes farming was studied. According to the results obtained in [28], agrivoltaics on grapes farms increased the revenue by 15 times compared to traditional farms. Notably, the study concluded that if such agrivoltaics systems are replicated across India, they can generate $16,000 \mathrm{GWh}$ of electricity, which is enough to power 15 million households [28].

In a case study [43], agrivoltaics benefited Australia's state and federal government by reducing greenhouse gas emissions. Moreover, it was shown in [71] that the use of agrivoltaics in Turkey could produce $75 \%$ of the estimated electricity consumption in 2021. Similarly, according to Gonocruz et al., agrivoltaics with rice paddies in Japan can generate 284 million MWh/year [72]. Agrivoltaics showed effectiveness in electricity generation in rural and remote areas around the world. On the basis of evidence from India combined with global success, localized electricity production through agrivoltaics can effectively provide reliable and cheaper electricity to the rural parts of India.

\subsubsection{Water Conservation in Irrigation}

According to [73], efficient use of the water resources in a highly populated country such as India is necessary since $17 \%$ of the world population resides in India but has a minimal $4 \%$ of the water resources. Around $80 \%$ of this resource is used by the agriculture sector alone [74]. Additionally, in Maharashtra, which witnesses higher numbers of farmer suicide, one of the critical reasons is the flawed irrigation system and lower water table [75-77]. The results obtained in [76] concluded that irrigation networks in Maharashtra are ineffective despite the number of dams. Hence, farmers are too dependent on groundwater for irrigation, leading to table lowering of the water table in Maharashtra. Through satellite imaging, the groundwater data in Maharashtra were analyzed with the number of farmers' suicide [75]. It was found that groundwater level is strongly correlated with the number of farmers committing suicide [75]. The Indian farming sector is still dependent on monsoon rainfall. An insufficient monsoon rainfall means crop damage due to inadequate irrigation and an upsurge in farmers' suicide [78]. Hence, there is an urgent requirement of the techniques in agriculture to provide efficient irrigation techniques for agriculture.

A recent study in agrivoltaics spread across six acres of farmland at the Oregon State University, Corvallis campus reveals that the water conversation improved by $328 \%$ due to solar panels [79]. The conservation of water happened due to solar panels acting as a barrier to water evaporation. The same is evident from the study conducted in Montpellier, France [80]. This study found that water balance improved by $10-30 \%$ in an agrivoltaics system when the light intensity was $50-70 \%$ of the full sun radiation [80]. Another modeling study conducted in the same city of France showed a reduction in water irrigation by $20 \%$ in lettuce farming. The use of tilting-angle solar panels' integration with the farm leads to 
water conservation in irrigation [57]. Similarly, in [61], it is shown that significant water preservation is achieved from agrivoltaics for locations with above-average temperatures and disproportionate solar radiations. India, where most of the landmass experiences warm weather throughout the year, will substantially reduce water evaporation from agrivoltaics.

\subsubsection{Farm Yield Improvement}

In an experiment conducted in Fuyang, China, the impact of an even-lighting agrivoltaics system on crop yield was tested. The even-lighting system resulted in quicker crop yield and an improvement in the quality of the harvest [81]. Similarly, a study conducted at the Institute of Technology in the city of Ichihara, Japan, showed significant yield improvement in shade-intolerant crops [82]. The same was the case with the shade-tolerant crops. In another research project, agrivoltaics was found to protect crops from hailstorms [83]. Additionally, a considerable improvement in the biomass in the soil was found underneath solar panels, which further enhances the harvest of vegetables [84]. It must be noted that vegetables are a highly valued cash crop that can double farmers' income [85-88].

\subsubsection{Income Generator}

The unreliable farming practices used by the farmers in India made it difficult for many to survive in this sector. Hence, in the past couple of decades, India saw an alarming rise in farmers' suicide. Some of the primary reasons are a low rate of return from agriculture, a high cost of production, poverty, indebtedness, unsecured loans, poor irrigation, and many others $[55,89]$. Much uncertainty is involved in agriculture since it takes significant time for the farmers to get a return on their investments. Between sowing and selling the crop, many uncertainties such as flooding, dryness, cyclone, or attack from animals, birds, and insects could damage the harvest and thus their prospect of returns on investments. Hence, farmers often raise domestic animals such as cows, buffaloes, goats, sheep, and hens to make returns more certain. They sell animal products such as milk, egg, and meat to supplement their agricultural income.

On similar lines, agrivoltaics also offers to generate additional income. A grid-tied solar panel enables farmers to sell the excessively generated electricity to utility companies. In [31,90], a grid-tied solar panel of $100 \mathrm{MW}$ installed on farmland of 6 acres in the Vidarbha region of India generated an income of $\$ 27,655$ per annum. Likewise, agrivoltaics-based rabbit farming systems generated additional revenues ranging from $\$ 7623-\$ 15,247 /$ year in Pennsylvania to \$8678-\$17,358/year in Wisconsin [91]. A study in Malaysia concluded that even with uncertain income from farming combined with the volatility of the market, agrivoltaics provides an economically feasible solution that is possible [92]. A feasible study conducted in agrivoltaics of $50 \mathrm{MW}$ in Maharashtra concluded that it has the potential to alleviate poverty with the addition of better water management for irrigation [69].

\subsubsection{Reduce the Pesticide Usage in Agriculture}

Since the beginning of the green revolution, Indian farmers started using high-yield seeds, fertilizers, and pesticides to increase crop produce [93]. According to the World Bank, pesticide usage in arable land in India is much higher compared to the rest of the world [65]. These details are presented in Table 1. The excessive use of pesticides results in land degradation [94]. The overuse of pesticides and fertilizers harms the soil and environment [95-97]. The pesticides even contaminate the groundwater, which results in farfetched impacts leading to life-threatening diseases [98]. For example, the Malwa region of Punjab, India, is labeled the "cancer capital" due to the high number of cancer cases. In addition, the region has seen a significantly high number of mental and reproductive diseases. These diseases are all linked to groundwater contamination caused by the indiscriminate usage of pesticides and fertilizers [99]. 
Table 1. Pesticides' consumption across the World and India in Kilogram per Hectare of arable land according to the World Bank's Sustainable Energy for All (SE4All) database fertilizer [65].

\begin{tabular}{ccc}
\hline Year & World (Kilogram per Hectare) & India (Kilogram per Hectare) \\
\hline 2005 & 117.4 & 127.6 \\
2006 & 120.2 & 136.4 \\
2007 & 126.5 & 142.8 \\
2008 & 120 & 153.4 \\
2009 & 118 & 167.5 \\
2010 & 130.1 & 179 \\
2011 & 135.4 & 180.7 \\
2012 & 131.9 & 163.1 \\
2013 & 134.5 & 156.5 \\
2014 & 139 & 163.5 \\
2015 & 135.8 & 171 \\
2016 & 138.2 & 166 \\
2018 & 138.9 & 170 \\
\hline
\end{tabular}

Agrivoltaics were reported to reduce pesticides in some preliminary research. According to an experiment conducted in the Negev Desert, agrivoltaics consisting of monofacial solar panels enabled reducing pesticides in vegetable farming [61]. As per [62], an agrivoltaics system protected crops from weather and provided good ventilation, which reduced the use of pesticides on a farm in the Netherlands. Similarly, a survey in Topaz Solar Farm's project in San Luis Obispo County, CA found that the solar system's use can help avoid using pesticides and fertilizers [100].

\subsection{Weakness}

\subsubsection{Cost of Solar Panels}

Solar-based electricity generation has the potential of rural electrification, ensuring economic development when complemented with social and economic infrastructure development [101]. These renewable energy sources being low on maintenance costs make them ideal for rural electrification [102]. However, one of the hurdles for the mass adoption of solar-based electricity generation is their high capital and installation costs [101-103]. One of the ways the high cost of solar panels can be reduced is by local production. The rate of interest on loans offered to solar system manufacturers and end-users is fairly high. Moreover, the cost of the utility for local manufacturing plants is also quite steep in India. Hence, the manufacturing cost of solar systems in India is higher as compared to other manufacturers in Asia. Moreover, Khare et al. identified the dependency on imported wafers for solar cell manufacturing, high cost of capital, lack of technical knowledge, and competition from neighboring countries such as China and Taiwan as some of the challenges keeping the solar cells' costs high [104]. Hence, unless the prices of the solar panels are reduced, it will be a complex stint to convince the farmers to add solar farming to their agricultural land and reap its benefits.

\subsubsection{No Government Incentives}

Around the world, there is an increase in the adoption of solar-based electricity generation. One of the fundamental driving forces behind this increase is the availability of government subsidies and incentives. In [105], various government initiatives were presented in countries such as the United States of America, Canada, Germany, France, China, Spain, and Australia, which include feed-in-tariffs, portfolio standards, tax credits, pricing laws, production incentives, trading schemes, and others. Due to government support, there is a significant rise in sun-powered energy generation capacity, as shown in Figure 11. 


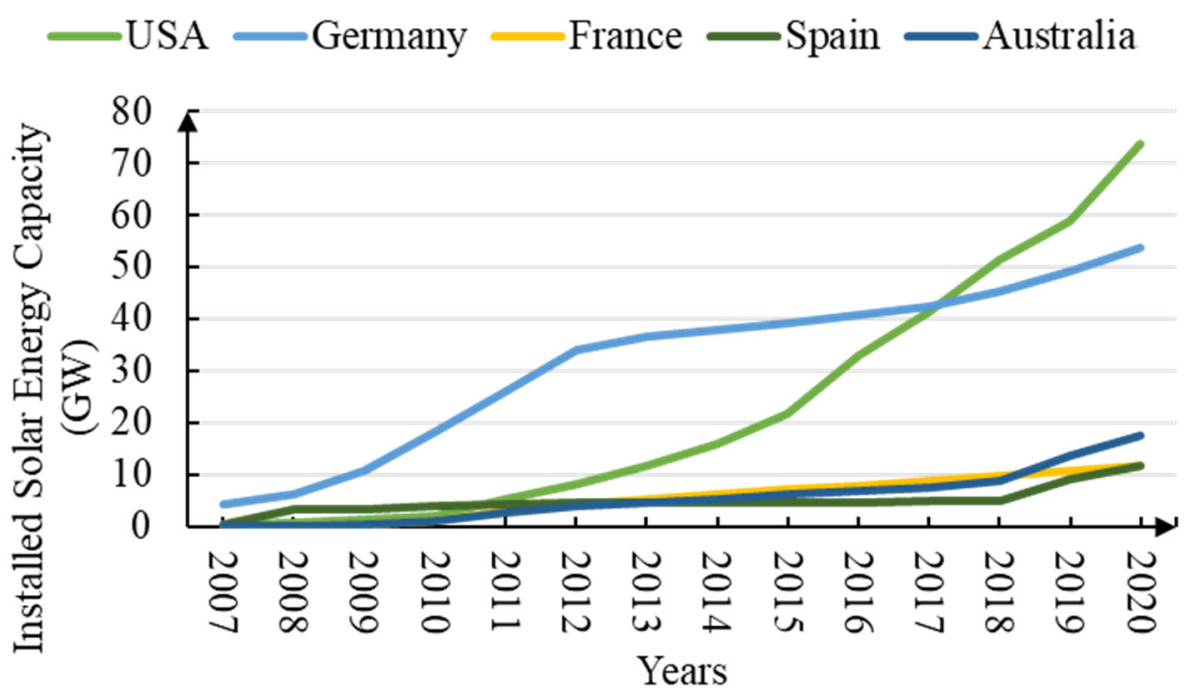

Figure 11. Installed solar energy capacity as per the Statistical Review of World Energy reported in 2021.

One of the key barriers identified by Burke et al. that prevents the Indian population from adopting solar energy is the government's considerable subsidy on fossil fuels and electricity [106]. Instead, the government of India should give more assistance and incentives for solar energy that will make them more affordable than fossil fuels.

In [102], a list of incentives offered by the GOI on solar-based electricity generation is presented. The incentives include no excise duty on the domestic manufacturing of solar energy devices and systems, no import duty or concession on specific systems associated with solar energy, and many others. These incentives are encouraging. However, the GOI needs to provide more incentives to support agrivoltaics in India. Many countries such as the United States of America, Canada, Germany, France, China, Spain, and Australia have provided tailored incentives to fit government-specific initiatives, and they have been largely successful. For example, the US provides several incentives for solar and clean energy systems. Many of such incentives succeeded in capturing the attention of end-users and provided significant end-users' acceptance. The GOI may also consider offering attractive incentives for getting end users' attention and thus, their acceptance.

\subsubsection{Lack of Social Awareness and Fear of Failure}

There exists a widespread unawareness about agrivoltaics in the farming community. Similar to any other profession, maintaining and operating a solar power plant requires specialized skills and training. The experts are not willing to relocate to the rural part of India to train the local population without getting substantial perks [107]. The lack of knowledge threatens the non-implementation of agrivoltaics, thus remaining devoid of the potential benefits this methodology could offer. So there exists a need to educate the farming community about the proper implementation of agrivoltaics. However, just educating farmers may not work alone.

A semi-structured study was conducted in the 700 households in Uttar Pradesh, India [108]. It was found that only raising awareness of solar technology and giving subsidies on renewable energy are not enough for the mass adoption of clean energy [108]. The same study found that government campaigns and ads in print and electronic media are insufficient to raise awareness of solar energy [108]. Instead, many households prefer word of mouth, experiential learning, and village-level awareness programs [108]. It was reported in [57] that farmers switching to agrivoltaics, when interviewed, presented the positive aspects of using this technology as a result of getting a stable income and sustainable agriculture yield. Having such farmers across the rural parts of India can effectively spread mass awareness of agrivoltaics. The GOI should take concerted steps to 
create such technology-champion-farmers by piloting selective projects and giving them first-hand exposure to the agrivoltaics approach.

Moreover, there exists a fear of failure in the farming community, just as in any other business community. The fear is one of the failures that is a deterrence to the widespread adoption of the agrivoltaics approach, and that requires government agencies to develop innovative ways to educate farmers and thus help them make informed decisions so that the fear of failure is reduced.

\subsubsection{Solar Systems after Decommissioning}

Typically, solar cells are made up of toxic chemicals such as lead, cadmium, selenium, and others that can cause harm to human beings, flora, and fauna if not disposed-of properly. The other vital components associated with the solar system, such as batteries and inverters, also have hazardous chemicals that require appropriate disposal. According to [109], between 2020 to 2047, 2.95 billion tons of e-waste will be generated at the end-oflife of solar systems. The wider acceptance and deployment of agrivoltaics will further aggravate the e-waste generated by solar panel disposal. As per the Central Pollution Control Board (CPCB), India only recycles $4 \%$ of its total e-waste by the organized sector [110]. Hence, at this time, it appears that India is not prepared to handle the mass e-waste generated by solar systems [111]. Owing to the enormous quantities of e-waste from agrivoltaics, the GOI needs to develop policies to address this issue. Otherwise, agrivoltaics, instead of benefiting, will give rise to gigantic heaps of e-waste.

\subsubsection{Degradation of Solar Systems}

Solar systems are exposed to natural elements such as temperature, wind speed, dust accumulation, irradiance, humidity, and physical stress, which degrade the output capacity of the solar systems [112]. As per NREL studies, the solar systems degrade at a rate of $0.5 \%$ per year. The degradation rate implies that with a solar system's life span varying from 20 to 25 years, the aging solar systems will produce less than $90 \%$ of electricity compared to the production in year 1 [113]. A study of solar panels used in India over a period of ten years showed worrisome results. The study was conducted on solar systems that had panels made while following International Electrotechnical Commission (IEC) standards, IEC61215 to be specific. Even though the panels were made using IEC standards, they were affected in different ways. The study found that panels had degradation from $8 \%$ for the best performing panels to $28 \%$ for the worst performing panels. The study attributed the better performance to carefully fabricated panels, using good-quality raw material, and other quality control practices while manufacturing [114]. Hence, we can safely conclude that to overcome this weakness, the GOI should ensure strict quality control in solar systems manufacturing.

\subsection{Opportunities}

\subsubsection{Increase in Demand for Solar Energy}

The adoption and success of Agrivoltaics will lead to social awareness regarding the benefits of switching to renewable energy. This was considered a significant barrier towards accepting solar as one of the options for electricity generation $[40,115,116]$. Social awareness will fuel other applications where solar energy can be used, such as residential homes and buildings, commercial buildings, vehicles, portable electronic devices, and many others. Additionally, local awareness of solar energy will lead to increased demand and push the government to strengthen local manufacturers to make solar panels locally. The Government of India (GOI) has already shown dedication to local manufacturing with its Make in India initiative. Hence, strengthening the local solar industry is an opportunity that aligns well with its current initiative. 


\subsubsection{Rise in Local Manufacturing of Solar Panels}

Post COVID-19, the supply chains were disrupted, which provides India opportunities to promote local manufacturing for energy security and prevent such future uncertainties [117]. The possibility of the widespread adoption of agrivoltaics will be one such catalyst in giving the much-needed momentum to the local solar system manufacturers and policymakers to incubate a self-reliant local supply chain. Such momentum can cause a surge in demand for solar panels, leading to an upswing of many such manufacturing units. Eventually, this will provide employment opportunities for the local population as well. All these will drive down the costs associated with solar systems in the country. Thus, a supply chain disruption due to the pandemic can make local production more attractive than ever before.

\subsubsection{Lowering of Greenhouse Gas Emissions}

India is the third-largest contributor to greenhouse emissions $[9,90]$. The sector-wise contribution to greenhouse gas emission in India for the year 2016 is shown in Figure 12. Electricity, agriculture, and manufacturing/construction are the major contributors to greenhouse emissions. With agrivoltaics, additional electricity can be generated, and that will reduce the dependence on coal-based power plants. Agriculture contributes to greenhouse gas emissions due to methane gas produced by livestock such as cows, buffaloes, and others [118].

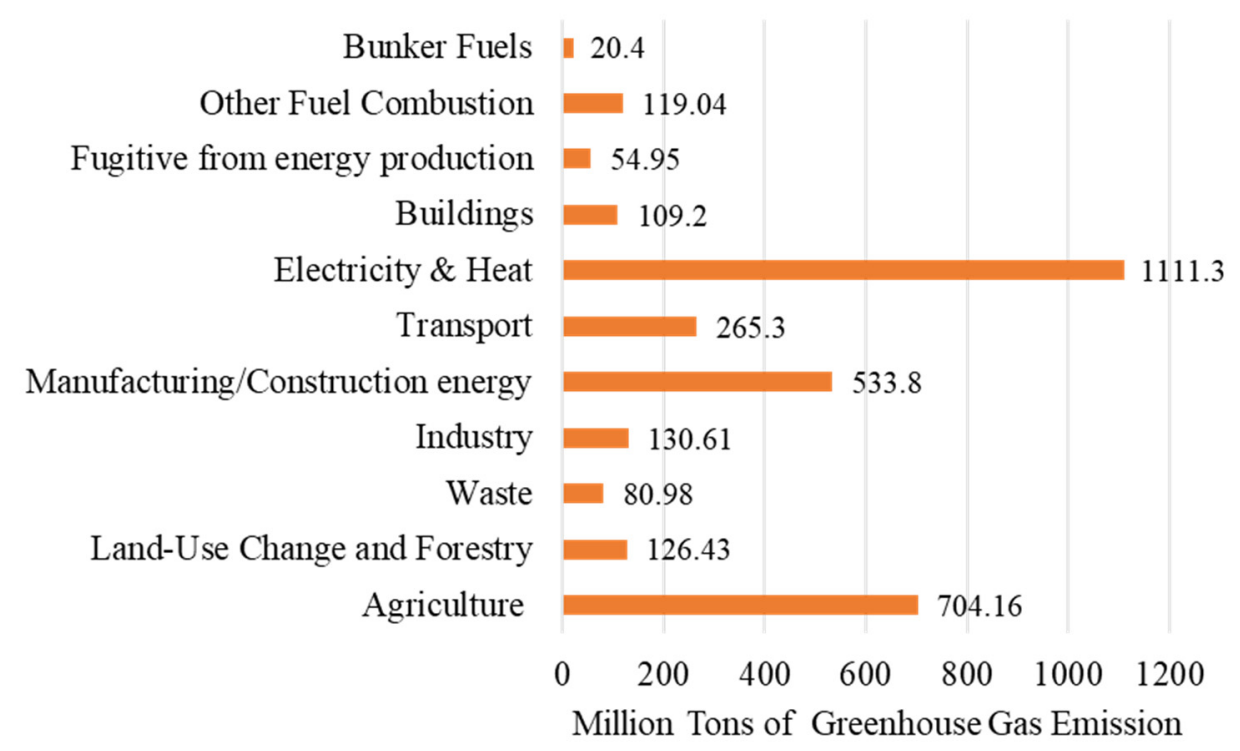

Figure 12. Sector wise greenhouse gas emissions, India, 2016. Data Source: https:/ / ourworldindata. org/energy (2 April 2021).

Additionally, the excess use of fertilizers in farmland contributes to nitrous oxide, another greenhouse gas [119-121]. Moreover, farmers depend on livestock for a secondary income and their utility in farms. For every liter of milk, $3 \mathrm{~kg}$ of GHG are produced [122]. Alarmingly, the GHG generated by the livestock mainly consists of methane which is considered more harmful for global warming since it absorbs much more infrared compared to $\mathrm{CO}_{2}$ [123]. The agrivoltaics as a source of secondary income generation will ultimately decrease this dependence on livestock, thereby reducing the excessive methane gas production.

\subsection{Threat}

\subsubsection{Solar Panel Theft}

According to [124,125], India was ranked 53rd among 117 counties in 2016 based on the world crime index. One of the crimes that the rural part of India is mainly affected 
by is theft, which is statistically found to be significantly caused by weather and trade shocks [126]. Poverty is another factor that causes a rise in crime in rural India [52]. Since solar panels are installed in the open and have a high value, they face an imminent threat of being stolen. A study was conducted to analyze the effectiveness of solar-based mini-grid deployment for electrifying the rural part of Chhattisgarh, India [127]. According to the study, the solar mini-grid successfully electrified the eight project sites selected in the two districts, Raipur and Korba in Chattisgarh. The two problems found in this study were mortgaging the solar panels when the user faced economic stress and theft, which reversed the purpose of deployment [127]. The same issues were reported in Moamba, Mozambique, where solar panels were used for irrigation purposes [128]. Hence, the burglary of solar panels can be determinantal to further adoption by other individuals directly involved in agriculture.

Therefore, it is necessary to develop a mechanism that can prevent the theft of solar panels. Installing solar panels at elevation was presented as one of the solutions in agrivoltaics for preventing its theft [129]. In the worst case of burglary, the stolen solar panels should be tracked such that the culprits are caught and punished. Additionally, it is necessary to develop financial avenues or safety nets that rural farmers can utilize in case of theft of the solar panel. For example, a solar panel insurance scheme can provide compensation to the farmer in case of theft to save themselves from financial distress.

\subsubsection{Lack of Proper Insurance}

India, over the years, has witnessed extreme weather such as earthquakes, floods, and cyclones. Floods and cyclones are hydro-meteorological disasters that resulted in damaging crops [130-134]. According to [130,135-137], such climate extremes will increase in the future due to climate change. Hence, the solar panel installed in the farmland will get damaged due to such extreme weather conditions. Therefore, it is also necessary to have proper insurance schemes where farmers can recover their investment in case of damage due to extreme weather. The same is true in the case of the theft of solar panels. As per a report published by the International Renewable Energy Agency (IRENA), the most environmentally preferable option for tackling end-of-life solar panels is repairing and reusing [138]. If fault or defect are found in the early life phase of installed solar panels, the farmers should get proper insurance or warranties. That way, they can get repairs or replacements of defective solar panels. Additionally, there are faults such as hot-spot, double-ground, and arcs that have the potential of causing a fire hazard in solar panels [139-141]. Therefore, for such kinds of incidents as well, there is a requirement for an insurance cover.

According to a survey on situation assessment conducted in 2013, more than $90 \%$ of the farmers did not insure a single crop even after getting government subsidies [142]. This points towards a need to educate the farming community to hedge potential risks of farming and related impacts. Hence, for integrating solar panels with agriculture, the awareness of having an insurance scheme for both the crop and solar panels is critical.

\subsubsection{Competition from Other Sustainable Farming Techniques}

Governments around the world are tasked with maximizing benefits using limited resources. For developed countries, the resources can be used more efficiently because they already have a system that provides basic minimum living standards. However, for developing countries, especially India, the challenge is to take care of basic needs as well as to keep up with the developmental requirements. So, there are competing alternatives for each dollar available and thus a race for the fittest technology. Several alternatives could give a tough competition to agrivoltaics in India.

A study conducted by the Council of Energy, Environment, and Water (CEEW) in 2021 identified several viable options for making agriculture sustainable in India [143]. This was in collaboration with the Food and Land USE Coalition (FOLU) [143]. The 
study identified 16 alternatives that made agriculture sustainable in India. The popular techniques identified in the study are listed in Table 2.

Indian farmers are majorly dependent on the monsoon and groundwater for irrigation [144], thus increasing the need to manage water efficiently. The use of the drip irrigation technique improved the efficiency in water usage in agriculture and simultaneously improved cultivation productivity [145-147]. Similarly, rainwater harvesting is also considered a viable option for creating a sustainable irrigation alternative for farming in India [18,148-150].

Intercropping is another technique that is used for creating sustainable agriculture. In this technique, different plant species are grown simultaneously in the same farmland [151]. It is shown that the intercropping of pearl millet and green gram in Rajasthan resulted in increasing the benefit to cost ratio, nutrient uptake, and many other benefits [152]. An experiment was conducted where baby corn and legume were intercropped in the eastern plateaus of India [153]. The investigation showed that the intercropping of baby corn with legumes increased productivity per unit area, improved land-use efficiency, and improved the atmospheric nitrogen fixation process [153].

According to [154], agroforestry means producing food with fodder and firewood simultaneously by growing crops with shrubs and trees. It was also reported in [154] that agroforestry improves biodiversity, increases the yield of goods and services to society, enhances soil fertility, and results in many other benefits.

Table 2. Farming techniques for making agriculture sustainable.

\begin{tabular}{|c|c|c|c|c|c|c|}
\hline $\begin{array}{l}\text { Farming } \\
\text { Technique }\end{array}$ & References & $\begin{array}{l}\text { Increase in } \\
\text { Income }\end{array}$ & $\begin{array}{c}\text { Yield } \\
\text { Improvement }\end{array}$ & Reduce GHG & Electrification & $\begin{array}{c}\text { Low Adoption } \\
\text { Cost }\end{array}$ \\
\hline $\begin{array}{l}\text { Organic } \\
\text { Farming }\end{array}$ & {$[56,155]$} & $\checkmark$ & & $\checkmark$ & & $\checkmark$ \\
\hline $\begin{array}{c}\text { Sustainable } \\
\text { Water Irrigation }\end{array}$ & [145-147] & $\checkmark$ & $\checkmark$ & $\checkmark$ & & $\checkmark$ \\
\hline Intercropping & {$[152,153]$} & $\checkmark$ & $\checkmark$ & $\checkmark$ & & $\checkmark$ \\
\hline Agroforestry & [154] & $\checkmark$ & $\checkmark$ & & & $\checkmark$ \\
\hline $\begin{array}{l}\text { Precision } \\
\text { Farming }\end{array}$ & {$[156,157]$} & $\checkmark$ & $\checkmark$ & & & \\
\hline Agrivoltaics & [26] & $\checkmark$ & $\checkmark$ & $\checkmark$ & $\checkmark$ & \\
\hline
\end{tabular}

Another alternative is precision farming, wherein advanced technology is used with agriculture, such as the Internet of Things (IoT), the wireless sensor network, GPS on tractors, drones, soil health cards, and many others that increase farm yield [158]. In precision farming, by using information fertilizers, irrigation, and seeds that are applied on the farms based on their soil health, this enabled making agriculture sustainable [158]. The current status, future adoption strategies, and impact of precision farming in India and other developing nation were reported in [156,157].

Organic farming is an old practice in India where crops are grown without chemical fertilizers and pesticides. The excess usage of fertilizers and pesticides leaves behind their residues in the crops, farmland, and groundwater [155]. This could harm flora and fauna by getting in the food and water cycle, and the impact could be realized over several years. However, in recent times, there has been a growing awareness about the benefits of organically grown crops, thus increasing their demand [159]. Customers are willing to pay premium amounts for organically grown food which is propping the costs upward and thus making them unreachable for most of the Indian population.

The different alternatives presented in Table 2 offer benefits that provide some considerable competition to agrivoltaics. However, agrivoltaics is the only option that can provide rural electrification and thus a stable source of secondary income. 


\section{Discussion}

The use of agrivoltaics offers many key benefits to a densely populated country such as India. The benefits include rural electrification, water conservation, agriculture yield improvement, and sustainable income generation. Through the mass deployment of agrivoltaics across India, its population can efficiently utilize its vast landmass to generate green energy, food, and a steady income. The three pillars of sustainability are people, environment, and economy. The strengths identified during this SWOT analysis are found to be improving people's quality of life, thus concurring with sustainability's people pillar; saving natural resources, thus concurring with sustainability's environment pillar; providing ways to economic stability, thus concurring with sustainability's economics pillar. Agrivoltaics being sustainable, the farming community's instances of distress are expected to decrease and therefore will also enable the government to stabilize the community. Besides being sustainable, technological advancements also indicate a continued improvement.

In the last decade itself, there was a downward trend in the cost of solar panels [160]. Many innovations led to significant improvements in their performance. The recent advances in solar cell manufacturing techniques increased silicon-based solar cells' efficiency to $29.4 \%$ [161], which was $25 \%$ in 2011 [162]. Similarly, the efficiency of more expensive multi-junction solar cells has reached $43.4 \%$ [163]. Recently, in [164], switch embedded solar panels showed better performance in partial shading conditions than conventional solar panels. Such advanced solar panels in agrivoltaics will make them even more efficient during varying lighting conditions. Simultaneously, improvement in the sun-tracking technology [165,166] and MPPT [167-169] can make agrivoltaics even more desirable than before. Therefore, with the advancement in solar cell manufacturing techniques, sun-tracking technology, and MPPT algorithms, the electricity generation capacity of agrivoltaics under varying lighting conditions will also increase in the future. This will result in increasing the farmers' income. Hence, agrivoltaics is an excellent approach and should be pursued in India.

The GOI can address the weaknesses found in the SWOT at the policy levels. The GOI championed many policies that impacted the social and economic outlook of the country. For example, the GOI implemented the Green Revolution, which doubled wheat and rice production since the 1960s [170], launched Operation Flood, which increased the annual milk production rate from $0.7 \%$ to $4.7 \%$ [171], enabled telecom reform in 1994, which helped billions of people to get access to telecom and smartphones [172], spearheaded the Make In India Initiative in 2014, which has been boosting the manufacturing sector of the country [173], and rolled out the Soil Health Card report initiative in 2015 that helps farmers make informed decisions about farming [174]. Each of these policies, in addition to many others, offers simultaneous benefits. For example, the GOI initiated the program to educate farmers by providing the soil health card report [174]. This report enables farmers to know about their soil type, their composition, and other related information. This information is then used to identify the best suitable crops for their farm. All these help farmers know more about their farm soil and make informed decisions. However, on the other hand, the initiative also strengthens farmers' economic condition because the information helps them to get maximum crop yield from their farms. So, with a proven track record, it is evident that the country has consistently implemented policies that uplift the country socially and economically. It is just a matter of time that if the government decides, it can address the weaknesses and make agrivoltaics a norm in the country.

By offering incentives to local and foreign investors to set up manufacturing plants in India, the GOI can lower the prices of solar panels in the future. At the same time, by doling out subsidies to its population for using solar-based energy sources, the GOI can substantially stimulate the awareness towards green energy and reduce their cost of adoption. The paper by [115] highlights many of the recent steps taken by policymakers in India to promote local manufacturing. Additionally, educational and training institutes in the rural parts of India should be set up where the local population can be trained for the 
maintenance and operation of solar plants. Although operating agrivoltaics requires lower maintenance, hands-on training received for the educational institutions in the rural parts will ensure the longevity and proper functioning of solar panels.

A comparison of the impacts of solar energy on the environment is presented in [175]. As per this review article, Tawalbeh et al. found that the carbon footprint emission from solar energy production is 10 to 53 times smaller compared to energy produced by traditional methods [175]. While these emission reductions are impressive, the footprint can be further reduced by proper recycling.

The solar panels installed in the agrivoltaics reaching end-of-life through the proper recycling mechanism can generate massive revenue. According to an estimate by Gautam et al., the 2.95 billion tons of waste produced in the end-of-life solar panel will consist of $51 \%$ glass, 31\% aluminum, $6 \%$ copper, and another 21 metals [109]. A proper recycling mechanism of these metals can generate a revenue of around $\$ 452$ trillion [109]. This estimate does not consider the broader acceptance of agrivoltaics proposed in this work. Due to the considerable revenue generation opportunity available in this area, it has the potential of attracting massive investment in this area. This can result in creating a whole ecosystem of recycling the e-waste, which, if ignored, will be a huge problem for a very populated country such as India. A dedicated investment plan in recycling e-waste can generate employment opportunities for the local population.

Though agrivoltaics offers India many salient opportunities to move towards sustainability, the biggest hurdle is financing such a project. Hence, it can be considered as one of the categories in the weakness subsection in the SWOT analysis. Since the farmers in the rural part of India are already under financial stress, it will be impractical to expect them to take financial responsibilities and risks by installing solar panels. Policymakers should develop policies to overcome financial hurdles and allow local utility companies to partner with farmers to install solar panels. That way, local utility companies will be able to partner with farmers and enable the latter to take lesser risks by way of transferring only those risks that are manageable by the farmers.

The utility companies supplying electricity to the rural parts of India are generally in poor financial conditions due to heavy subsidies given to farmers, distribution losses due to remoteness, and electricity theft [176]. Hence, they often do not see any incentive in providing reliable electricity to the rural parts of India. The distribution losses are generally reduced by having a local power plant in the rural parts. However, stringent land acquisition bills make it almost impossible for utility companies to build such power plants. By having the provision for public-private partnership, these kinds of projects can become feasible wherein the utility companies and the government provide funds for purchasing and installing solar panels in the farmland. In return, utility companies will get access to the farmland to build solar-based power plants to reduce the distribution losses. In this arrangement, the farmers will get part of the profit generated by electricity production and the monthly lease amount for providing their farmland with installed solar panels. Over the years, Indian federal and state governments have offered loan waiver schemes for the farmers [177-181]. Instead, taxpayers' money can be better utilized by funding such projects, which make farming sustainable in collaboration with utility companies.

\section{Conclusions}

India is dependent on the farming sector, but despite being omnipresent throughout the country, the contribution to its GDP is limited. Many farmers and people employed in the farming sector struggle financially due to dependence on unreliable farming techniques and a lack of awareness about advancements in technology. India being the biggest democracy in the world has played a significant role globally and emerged as an important player in food security, exports, technology development, and medicine. For example, India has been part of the PCA, which requires its member nations to reduce GHG emissions and increase its clean energy production capacity. Hence, India's efficiency and stability are important for regional and global progress. Indian farmers need to adopt CSA alternatives 
to counter the challenges they are facing. This paper presents the study and results of the suitability of agrivoltaics, a CSA alternative, for the Indian farming sector that satisfies all the objectives of CSA. The SWOT analysis about agrivoltaics for the Indian farmers is presented in this paper.

In general, the research results showed that

- Agrivoltaics has the potential to provide rural electrification, water conservation, yield improvement, sustainable income generation, and reductions in the usage of pesticides and fertilizers.

- Agrivoltaics will be a tool to reduce farmers' financial distress.

- Regions that have a higher number of suicides are also ideal for agrivoltaics, making it an alternative choice.

- The adoption of solar energy will contribute to opportunities for local manufacturing, which will eventually lower the cost of solar panels in India. Moreover, such local manufacturing will provide employment opportunities and thus strengthen the economic structure of the country.

- Thus, it is rational to assume that agrivoltaics could emerge as a one-shot solution to several socio-economic problems.

- India being a close-knit and well-connected society, the initial success of agrivoltaics is expected to increase social awareness, leading to a quick adoption of the technique throughout the nation.

However, for farmers to embrace agrivoltaics, the GOI needs to take the following policy-related steps for the broader acceptance of agrivoltaics:

- The GOI needs to design policies that provide financial support for purchasing and installing solar panels apart from providing insurance coverage to cover unforeseen events such as thefts or damage.

- Additionally, agrivoltaics is an excellent opportunity for the GOI to structure innovative policies such as public-private partnerships wherein power companies can collaborate with farmers for mutually beneficial outcomes such as increasing clean energy production, reducing GHG emissions, and providing rural electricity, income stability, and sustainable farming.

- Provide education and training to the rural population in maintaining the solar farm and the kind of crop suitable based on the time of the year and geographical location.

- The mass acceptance of agrivoltaics will be followed by an imminent end-of-life solar e-waste generation in significant quantities. The GOI must remain mindful of the upcoming issue and design policies that enable the country to turn the tables around by making the best out of waste.

With a proven track record of successfully implementing a wide variety of policies, the widespread adoption of agrivoltaics in India seems to be just a few years away after the GOI starts focusing on its adoption.

Author Contributions: Each author contributed equally to this paper. All authors have read and agreed to the published version of the manuscript.

Funding: This research received no external funding.

Institutional Review Board Statement: Not applicable.

Informed Consent Statement: Not applicable.

Data Availability Statement: Not applicable.

Acknowledgments: The authors would like to thank Kathleen Preston, Ph.D., FDC-ORSP Quantitative Research Coordinator/Fellow from the Faculty Development Center (FDC) at California State University, Fullerton (CSUF), for her valuable inputs during the initial structuring of this article.

Conflicts of Interest: The authors declare no conflict of interest. 


\section{References}

1. Graichen, J.; Healy, S.; Siemons, A.; Höhne, N.; Kuramochi, T.; Gonzales-Zuñiga, S.; Sterl, S.; Kersting, J.; Wachsmuth, J. International Climate Initiatives - A Way Forward to Close the Emissions Gap? Initiatives' Potential and Role under the Paris Agreement; Final Report; Umweltbundesamt: Dessau-Roßlau, Germany, 2017.

2. Raiser, K.; Kornek, U.; Flachsland, C.; Lamb, W.F. Is the Paris Agreement Effective? A Systematic Map of the Evidence. Environ. Res. Lett. 2020, 15, 083006. [CrossRef]

3. Madurai Elavarasan, R.; Selvamanohar, L.; Raju, K.; Rajan Vijayaraghavan, R.; Subburaj, R.; Nurunnabi, M.; Khan, I.A.; Afridhis, S.; Hariharan, A.; Pugazhendhi, R.; et al. A Holistic Review of the Present and Future Drivers of the Renewable Energy Mix in Maharashtra, State of India. Sustainability 2020, 12, 6596. [CrossRef]

4. Teske, S. Achieving the Paris Climate Agreement Goals: Global and Regional 100\% Renewable Energy Scenarios with Non-Energy GHG Pathways For+ 1.5 C And+ 2 C; Springer Nature: Cham, Switzerland, 2019.

5. Lacal Arantegui, R.; Jäger-Waldau, A. Photovoltaics and Wind Status in the European Union after the Paris Agreement. Renew. Sustain. Energy Rev. 2018, 81, 2460-2471. [CrossRef]

6. Masson-Delmotte, V.; Zhai, P.; Pirani, A.; Connors, S.L.; Péan, C.; Berger, S.; Caud, N.; Chen, Y.; Goldfarb, L.; Gormis, M.I.; et al. The Physical Science Basis. Contribution of Working Group I to the Sixth Assessment Report of the Intergovernmental Panel on Climate Change; IPCC, 2021; Cambridge University Press: Cambridge, UK, 2021.

7. US EPA. Global Greenhouse Gas Emissions Data. Available online: https://www.epa.gov/ghgemissions/global-greenhousegas-emissions-data (accessed on 25 October 2021).

8. US EPA. Overview of Greenhouse Gases. Available online: https:/ /www.epa.gov/ghgemissions/overview-greenhouse-gases (accessed on 25 October 2021).

9. Ritchie, H.; Roser, M. $\mathrm{CO}_{2}$ and Greenhouse Gas Emissions. Our World Data 2020. Available online: https://ourworldindata.org/ co2-and-other-greenhouse-gas-emissions (accessed on 31 July 2021).

10. Arias, P.; Bellouin, N.; Coppola, E.; Jones, R.; Krinner, G.; Marotzke, J.; Naik, V.; Palmer, M.; Plattner, G.-K.; Rogelj, J. Climate Change 2021: The Physical Science Basis. Contribution of Working Group14 I to the Sixth Assessment Report of the Intergovernmental Panel on Climate Change; Technical Summary; IPCC: Geneva, Switzerland, 2021.

11. Chaabouni, S.; Saidi, K. The Dynamic Links between Carbon Dioxide (CO2) Emissions, Health Spending and GDP Growth: A Case Study for 51 Countries. Environ. Res. 2017, 158, 137-144. [CrossRef]

12. Friedrich, J.; Ge, M.; Pickens, A. This Interactive Chart Shows Changes in the World's Top 10 Emitters. Available online: https:/ / www.wri.org/insights/interactive-chart-shows-changes-worlds-top-10-emitters (accessed on 19 July 2021).

13. Paladugula, A.L.; Kholod, N.; Chaturvedi, V.; Ghosh, P.P.; Pal, S.; Clarke, L.; Evans, M.; Kyle, P.; Koti, P.N.; Parikh, K.; et al. A Multi-Model Assessment of Energy and Emissions for India's Transportation Sector through 2050. Energy Policy 2018, 116, 10-18. [CrossRef]

14. Gulati, A.; Sharma, P.; Samantara, A.; Terway, P. Agriculture Extension System in India: Review of Current Status, Trends and the Way Forward; Indian Council for Research on International Economic Relations: New Delhi, India, 2018.

15. Bharti, N. Evolution of Agriculture Finance in India: A Historical Perspective. Agric. Financ. Rev. 2018, 78, 376-392. [CrossRef]

16. Sapkota, T.B.; Vetter, S.H.; Jat, M.L.; Sirohi, S.; Shirsath, P.B.; Singh, R.; Jat, H.S.; Smith, P.; Hillier, J.; Stirling, C.M. Cost-Effective Opportunities for Climate Change Mitigation in Indian Agriculture. Sci. Total Environ. 2019, 655, 1342-1354. [CrossRef]

17. Shukla, P.R.; Skea, J.; Calvo Buendia, E.; Masson-Delmotte, V.; Pörtner, H.O.; Roberts, D.C.; Zhai, P.; Slade, R.; Connors, S.; van Diemen, R. An IPCC Special Report on Climate Change, Desertification, Land Degradation, Sustainable Land Management, Food Security, and Greenhouse Gas Fluxes in Terrestrial Ecosystems; IPCC: Geneva, Switzerland, 2019.

18. Singh, R.; Singh, G.S. Traditional Agriculture: A Climate-Smart Approach for Sustainable Food Production. Energy Ecol. Environ. 2017, 2, 296-316. [CrossRef]

19. Calicioglu, O.; Flammini, A.; Bracco, S.; Bellù, L.; Sims, R. The Future Challenges of Food and Agriculture: An Integrated Analysis of Trends and Solutions. Sustainability 2019, 11, 222. [CrossRef]

20. Lipper, L.; Thornton, P.; Campbell, B.M.; Baedeker, T.; Braimoh, A.; Bwalya, M.; Caron, P.; Cattaneo, A.; Garrity, D.; Henry, K. Climate-Smart Agriculture for Food Security. Nat. Clim. Chang. 2014, 4, 1068-1072. [CrossRef]

21. Campbell, B.M.; Thornton, P.; Zougmoré, R.; van Asten, P.; Lipper, L. Sustainable Intensification: What Is Its Role in Climate Smart Agriculture? Curr. Opin. Environ. Sustain. 2014, 8, 39-43. [CrossRef]

22. Chel, A.; Kaushik, G. Renewable Energy for Sustainable Agriculture. Agron. Sust. Developm. 2011, 31, 91-118. [CrossRef]

23. Kanna, R.R.; Baranidharan, M.; Singh, R.R.; Indragandhi, V. Solar Energy Application in Indian Irrigation System. In Proceedings of the IOP Conference Series: Materials Science and Engineering; IOP Publishing: Bristol, UK, 2020; Volume 937, p. 012016.

24. Kumar, S.; Vyas, S.; Tirole, R.; Vyas, M.; Sharma, S.S.; Rao, S.S. Strategies to Enhance Solar Energy Utility in Agricultural Area of Rajasthan State, India. J. Phys. Conf. Ser. 2021, 1854, 012013. [CrossRef]

25. Jasrotia, S.; Kansal, A.; Kishore, V.V.N. Application of Solar Energy for Water Supply and Sanitation in Arsenic Affected Rural Areas: A Study for Kaudikasa Village, India. J. Clean. Prod. 2013, 60, 102-106. [CrossRef]

26. Pulipaka, S.; Peparthy, M. Agrivoltaics in India Overview of Operational Projects and Relevant Policies; National Solar Energy Federation of India (NSEFI): New Delhi, India; Indo-German Energy Forum Support Office (IGEF-SO): New Delhi, India, 2021.

27. Santra, P.; Meena, H.M.; Yadav, O.P. Spatial and Temporal Variation of Photosynthetic Photon Flux Density within Agrivoltaic System in Hot Arid Region of India. Biosyst. Eng. 2021, 209, 74-93. [CrossRef] 
28. Malu, P.R.; Sharma, U.S.; Pearce, J.M. Agrivoltaic Potential on Grape Farms in India. Sustain. Energy Technol. Assess. 2017, 23, 104-110. [CrossRef]

29. Chowdhury, K.; Mandal, R. Agrivoltaic: A New Approach of Sustainable Development. In Advances in Water Resources Management for Sustainable Use; Roy, P.K., Roy, M.B., Pal, S., Eds.; Lecture Notes in Civil Engineering; Springer: Singapore, 2021 ; pp. 513-522. ISBN 978-981-336-412-7.

30. Blankenship, B.; Kennedy, R.; Mahajan, A.; Wong, J.C.Y.; Urpelainen, J. Increasing Rural Electrification through Connection Campaigns. Energy Policy 2020, 139, 111291. [CrossRef]

31. John, R.S. Integrating Solar Farming with Agriculture for Rural Electrification and Self Employment. Master's Thesis, California State University, Fullerton, CA, USA, 2021.

32. Paliwal, R. EIA Practice in India and Its Evaluation Using SWOT Analysis. Environ. Impact Assess. Rev. 2006, 26, 492-510. [CrossRef]

33. Dos Santos, C.N.L. Agrivoltaic System: A Possible Synergy between Agriculture and Solar Energy. Master's Thesis, KTH Royal Institute of Technology, Stockholm, Sweden, 2020.

34. Katke, K. Precision Agriculture Adoption: Challenges of Indian Agriculture. Int. J. Res. Anal. Rev. $2019,6,863-869$.

35. Gurl, E. SWOT Analysis: A Theoretical Review. J. Int. Soc. Res. 2017, 994-1006. [CrossRef]

36. Bank, W. Doing Business 2019: Getting Electricity; The World Bank: Washington, DC, USA, 2019.

37. Welcome to Government of India-Ministry of Power. Available online: https:/ / powermin.gov.in/ (accessed on 26 July 2021).

38. Saraswat, S.K.; Digalwar, A.K.; Yadav, S.S.; Kumar, G. MCDM and GIS Based Modelling Technique for Assessment of Solar and Wind Farm Locations in India. Renew. Energy 2021, 169, 865-884. [CrossRef]

39. Hyvärinen, A. Wind Turbines over a Hilly Terrain: Performance and Wake Evolution. Ph.D. Thesis, KTH Royal Institute of Technology, Stockholm, Sweden, 2018.

40. Kar, S.K.; Sharma, A.; Roy, B. Solar Energy Market Developments in India. Renew. Sustain. Energy Rev. 2016, 62, 121-133. [CrossRef]

41. National Institute of Solar Energy: An Autonomous Institution of Ministry of New and Renewable (MNRE)—National Institute of Solar Energy. Available online: https:/ / nise.res.in/ (accessed on 27 July 2021).

42. Dhawan, V. Water and Agriculture in India: Background paper for the South Asia expert panel. In Proceedings of the Global Forum for Food and Agriculture, Berlin, Germany, 19-21 January 2017; Volume 28.

43. Chauhan, A.; Saini, R.P. Renewable Energy Based Off-Grid Rural Electrification in Uttarakhand State of India: Technology Options, Modelling Method, Barriers and Recommendations. Renew. Sustain. Energy Rev. 2015, 51, 662-681. [CrossRef]

44. Manju, S.; Sagar, N. Progressing towards the Development of Sustainable Energy: A Critical Review on the Current Status, Applications, Developmental Barriers and Prospects of Solar Photovoltaic Systems in India. Renew. Sustain. Energy Rev. 2017, 70, 298-313. [CrossRef]

45. Singh, S. Land Acquisition in India: An Examination of the 2013 Act and Options. J. Land Rural. Stud. 2016, 4, 66-78. [CrossRef]

46. Kulkarni, S.S.; Kulkarni, S.R.; Patil, S.J. Analysis of Population Growth of India and Estimation for Future. Int. J. Innovat. Res. Sci. Engin. Technol. 2014, 3, 843-850.

47. Vij, D. Urbanization and Solid Waste Management in India: Present Practices and Future Challenges. Procedia Soc. Behav. Sci. 2012, 37, 437-447. [CrossRef]

48. Agarwal, S.; Satyavada, A.; Kaushik, S.; Kumar, R. Urbanization, Urban Poverty and Health of the Urban Poor: Status, Challenges and the Way Forward. Demogr. India 2007, 36, 121-134.

49. Deshpande, T. State of Agriculture in India. PRS Legis. Res. 2017, 53, 6-7.

50. Behal, A. In India's Disorganized Agricultural Sector, a Connector of Crops to Markets. Forbes. 18 August 2015. Available online: https:/ / www.forbes.com/sites/abehal/2015/08/18/in-indias-disorganized-agricultural-sector-a-connector-of-cropsto-markets /?sh=7b7eea176a9d (accessed on 31 July 2021).

51. Singh, L.; Bhangoo, K.S.; Sharma, R. Agrarian Distress and Farmer Suicides in North India; Routledge India: New Delhi, India, 2019.

52. National Crime Records Bureau. Available online: http:/ / ncrb.gov.in/ (accessed on 21 June 2019).

53. Carleton, T. Crop-Damaging Temperatures Increase Suicide Rates in India. Proc. Natl. Acad. Sci. USA 2017, 114, 8746-8751. [CrossRef] [PubMed]

54. Bisht, I.S.; Rana, J.C.; Pal Ahlawat, S. The Future of Smallholder Farming in India: Some Sustainability Considerations. Sustainability 2020, 12, 3751. [CrossRef]

55. Merriott, D. Factors Associated with the Farmer Suicide Crisis in India. J. Epidemiol. Glob. Health 2016, 6, 217-227. [CrossRef] [PubMed]

56. Mariappan, K.; Zhou, D. A Threat of Farmers' Suicide and the Opportunity in Organic Farming for Sustainable Agricultural Development in India. Sustainability 2019, 11, 2400. [CrossRef]

57. Zainol Abidin, M.A.; Mahyuddin, M.N.; Mohd Zainuri, M.A.A. Solar Photovoltaic Architecture and Agronomic Management in Agrivoltaic System: A Review. Sustainability 2021, 13, 7846. [CrossRef]

58. Dinesh, H.; Pearce, J.M. The Potential of Agrivoltaic Systems. Renew. Sustain. Energy Rev. 2016, 54, 299-308. [CrossRef]

59. Willockx, B.; Herteleer, B.; Cappelle, J. Combining Photovoltaic Modules and Food Crops: First Agrovoltaic Prototype in Belgium. Renew. Energy Power Qual. J. (REEPQJ) 2020, 18. Available online: https://www.icrepq.com/icrepq20/291-20-willockx.pdf (accessed on 31 July 2021). 
60. Willockx, B.; Herteleer, B.; Cappelle, J. Theoretical Potential of Agrovoltaic Systems in Europe: A Preliminary Study with Winter Wheat. In Proceedings of the 2020 47th IEEE Photovoltaic Specialists Conference (PVSC), Virtual Meeting, 15 June-21 August 2020; pp. 996-1001.

61. Weselek, A.; Ehmann, A.; Zikeli, S.; Lewandowski, I.; Schindele, S.; Högy, P. Agrophotovoltaic Systems: Applications, Challenges, and Opportunities. Rev. Agron. Sustain. Dev. 2019, 39, 35. [CrossRef]

62. Toledo, C.; Scognamiglio, A. Agrivoltaic Systems Design and Assessment: A Critical Review, and a Descriptive Model towards a Sustainable Landscape Vision (Three-Dimensional Agrivoltaic Patterns). Sustainability 2021, 13, 6871. [CrossRef]

63. Jalali, S.; Wohlin, C. Systematic Literature Studies: Database Searches vs. Backward Snowballing. In Proceedings of the 2012 ACM-IEEE International Symposium on Empirical Software Engineering and Measurement, Lund, Sweeden, 19-20 September 2012; IEEE: New Jersey, NJ, USA, 2012; pp. 29-38.

64. Namugenyi, C.; Nimmagadda, S.L.; Reiners, T. Design of a SWOT Analysis Model and Its Evaluation in Diverse Digital Business Ecosystem Contexts. Procedia Comput. Sci. 2019, 159, 1145-1154. [CrossRef]

65. World Bank Open Data. Available online: https:/ / data.worldbank.org/ (accessed on 31 July 2021).

66. Malakar, Y. Evaluating the Role of Rural Electrification in Expanding People's Capabilities in India. Energy Policy 2018, 114, 492-498. [CrossRef]

67. Chakravorty, U.; Pelli, M.; Ural Marchand, B. Does the Quality of Electricity Matter? Evid. Rural India. J. Econ. Behav. Organ. 2014, 107, 228-247. [CrossRef]

68. Santra, P.; Pande, P.C.; Kumar, S.; Mishra, D.; Singh, R.K. Agri-Voltaics or Solar Farming: The Concept of Integrating Solar PV Based Electricity Generation and Crop Production in a Single Land Use System. Int. J. Renew. Energy Res. (IJRER) 2017, 7, 694-699.

69. Trommsdorff, M.; Vorast, M.; Durga, N.; Padwardhan, S. Potential of Agrivoltaics to Contribute to Socio-Economic Sustainability: A Case Study in Maharashtra/India; AIP Publishing LLC: Melville, NY, USA, 2021; Volume 2361, p. 040001.

70. Singla, P. Techno-Economic Analysis of AgriVoltaics for Punjab, India. Ph.D. Thesis, University of Groningen, Groningen, The Netherlands, 2021.

71. Coşgun, A.E. The Potential of Agrivoltaic Systems in Turkey. Energy Rep. 2021, 7, 105-111. [CrossRef]

72. Gonocruz, R.A.; Nakamura, R.; Yoshino, K.; Homma, M.; Doi, T.; Yoshida, Y.; Tani, A. Analysis of the Rice Yield under an Agrivoltaic System: A Case Study in Japan. Environments 2021, 8, 65. [CrossRef]

73. Jain, R.; Kishore, P.; Singh, D.K. Irrigation in India: Status, Challenges and Options. J. Soil Water Conserv. 2019, 18, 354. [CrossRef]

74. Harsha, J. Micro Irrigation in India: An Assessment of Bottlenecks and Realities. 2017. Available online: http://www. globalwaterforum.org/2017/06/13/micro-irrigation-in-india-an-assessment-ofbottlenecks-and-realities (accessed on 31 July 2021).

75. Chinnasamy, P.; Hsu, M.J.; Agoramoorthy, G. Groundwater Storage Trends and Their Link to Farmer Suicides in Maharashtra State, India. Front. Public Health 2019, 7, 246. [CrossRef]

76. Swain, S.; Sharma, I.; Mishra, S.K.; Pandey, A.; Amrit, K.; Nikam, V. A Framework for Managing Irrigation Water Requirements under Climatic Uncertainties over Beed District, Maharashtra, India. In Proceedings of the World Environmental and Water Resources Congress 2020: Water Resources Planning and Management and Irrigation and Drainage, Henderson, NV, USA, 17-21 May 2020; American Society of Civil Engineers: Reston, VA, USA, 2020; pp. 1-8.

77. Dongre, A.R.; Deshmukh, P.R. Farmers' Suicides in the Vidarbha Region of Maharashtra, India: A Qualitative Exploration of Their Causes. J. Inj. Violence Res. 2012, 4, 2-6. [CrossRef] [PubMed]

78. Thakur, M. An Economic Analysis of Plight of Farmers Suicide in India. SSRG Int. J. Econ. Manag. Stud. 2018, 5, 19-21.

79. Adeh, E.H.; Selker, J.S.; Higgins, C.W. Remarkable Agrivoltaic Influence on Soil Moisture, Micrometeorology and Water-Use Efficiency. PLoS ONE 2018, 13, e0203256. [CrossRef]

80. Marrou, H.; Dufour, L.; Wery, J. How Does a Shelter of Solar Panels Influence Water Flows in a Soil—Crop System? Eur. J. Agron. 2013, 50, 38-51. [CrossRef]

81. Zheng, J.; Meng, S.; Zhang, X.; Zhao, H.; Ning, X.; Chen, F.; Omer, A.A.A.; Ingenhoff, J.; Liu, W. Increasing the Comprehensive Economic Benefits of Farmland with Even-Lighting Agrivoltaic Systems. PLoS ONE 2021, 16, e0254482. [CrossRef] [PubMed]

82. Sekiyama, T.; Nagashima, A. Solar Sharing for Both Food and Clean Energy Production: Performance of Agrivoltaic Systems for Corn, A Typical Shade-Intolerant Crop. Environments 2019, 6, 65. [CrossRef]

83. Willockx, B.; Herteleer, B.; Ronsijn, B.; Uytterhaegen, B.; Cappelle, J. A Standardized Classification and Performance Indicators of Agrivoltaic Systems. In Proceedings of the 37th European Photovoltaic Solar Energy Conference and Exhibition, Lisbon, Portugal, 7-11 September 2020.

84. Weselek, A.; Bauerle, A.; Zikeli, S.; Lewandowski, I.; Högy, P. Effects on Crop Development, Yields and Chemical Composition of Celeriac (Apium Graveolens L. Var. Rapaceum) Cultivated Underneath an Agrivoltaic System. Agronomy 2021, 11, 733. [CrossRef]

85. Joshi, P.K.; Joshi, L.; Birthal, P.S. Diversification and Its Impact on Smallholders: Evidence from a Study on Vegetable Production. Agric. Econ. Res. Rev. 2006, 19, 219-236.

86. Mariyono, J.; Kuntariningsih, A.; Dewi, H.A.; Latifah, E.; Daroini, P.B.; Negoro, A.A.; Afari-Sefa, V.; Luther, G. Pathway Analysis of Vegetable Farming Commercialization. Econ. J. Emerg. Mark. 2017, 9, 115. [CrossRef]

87. Ponnusamy, K.; Devi, M.K. Impact of Integrated Farming System Approach on Doubling Farmers' Income. Agric. Econ. Res. Rev. 2017, 30, 233-240. [CrossRef]

88. Chand, R. Doubling Farmers Income: Strategy and Prospects. Indian J. Agric. Econ. 2017, 72, 1-23. 
89. Bhattacharyya, S.; Venkatesh, P.; Aditya, K.S.; Burman, R.R. The Macro and Micro Point of View of Farmer Suicides in India. Natl. Acad. Sci. Lett. 2020, 43, 489-495. [CrossRef]

90. John, R.; Mahto, R. Agrovoltaics Farming Design and Simulation. In Proceedings of the 2021 IEEE 48th Photovoltaic Specialists Conference (PVSC), Fort Lauderdale, FL, USA, 26 August 2021.

91. Lytle, W.; Meyer, T.K.; Tanikella, N.G.; Burnham, L.; Engel, J.; Schelly, C.; Pearce, J.M. Conceptual Design and Rationale for a New Agrivoltaics Concept: Pasture-Raised Rabbits and Solar Farming. J. Clean. Prod. 2021, 282, 124476. [CrossRef]

92. Othman, N.F.; Su, A.M.; Ya'acob, M.E. Promising Potentials of Agrivoltaic Systems for the Development of Malaysia Green Economy; IOP Conference Series: Earth and Environmental Science; IOP Publishing: Bristol, UK, 2018; Volume 146, p. 012002.

93. Rahman, S. Green Revolution in India: Environmental Degradation and Impact on Livestock. Asian J. Water Environ. Pollut. 2015, $12,75-80$.

94. Bhattacharyya, R.; Ghosh, B.N.; Mishra, P.K.; Mandal, B.; Rao, C.S.; Sarkar, D.; Das, K.; Anil, K.S.; Lalitha, M.; Hati, K.M.; et al. Soil Degradation in India: Challenges and Potential Solutions. Sustainability 2015, 7, 3528-3570. [CrossRef]

95. Sharma, N.; Singhvi, R. Effects of Chemical Fertilizers and Pesticides on Human Health and Environment: A Review. Int. J. Agric. Environ. Biotechnol. 2017, 10, 675-680. [CrossRef]

96. Prashar, P.; Shah, S. Impact of Fertilizers and Pesticides on Soil Microflora in Agriculture. In Sustainable Agriculture Reviews; Springer: New York, NY, USA, 2016; pp. 331-361.

97. Yargholi, B.; Azarneshan, S. Long-Term Effects of Pesticides and Chemical Fertilizers Usage on Some Soil Properties and Accumulation of Heavy Metals in the Soil (Case Study of Moghan Plain's (Iran) Irrigation and Drainage Network). Int. J. Agric. Crop. Sci. 2014, 7, 518.

98. Srivastav, A.L. Chemical Fertilizers and Pesticides: Role in Groundwater Contamination. In Agrochemicals Detection, Treatment and Remediation; Elsevier: Amsterdam, The Netherlands, 2020; pp. 143-159.

99. Mittal, S.; Kaur, G.; Vishwakarma, G.S. Effects of Environmental Pesticides on the Health of Rural Communities in the Malwa Region of Punjab, India: A Review. Hum. Ecol. Risk Assess. Int. J. 2014, 20, 366-387. [CrossRef]

100. Sinha, P.; Hoffman, B.; Sakers, J.; Althouse, L. Best Practices in Responsible Land Use for Improving Biodiversity at a Utility-Scale Solar Facility. Case Stud. Environ. 2018, 2, 1-12. [CrossRef]

101. Kamalapur, G.D.; Udaykumar, R.Y. Rural Electrification in India and Feasibility of Photovoltaic Solar Home Systems. Int. J. Electr. Power Energy Syst. 2011, 33, 594-599. [CrossRef]

102. Sharma, A. A Comprehensive Study of Solar Power in India and World. Renew. Sustain. Energy Rev. 2011, 15, 1767-1776. [CrossRef]

103. Urpelainen, J. Energy Poverty and Perceptions of Solar Power in Marginalized Communities: Survey Evidence from Uttar Pradesh, India. Renew. Energy 2016, 85, 534-539. [CrossRef]

104. Khare, V.; Nema, S.; Baredar, P. Status of Solar Wind Renewable Energy in India. Renew. Sustain. Energy Rev. 2013, 27, 1-10. [CrossRef]

105. Solangi, K.H.; Islam, M.R.; Saidur, R.; Rahim, N.A.; Fayaz, H. A Review on Global Solar Energy Policy. Renew. Sustain. Energy Rev. 2011, 15, 2149-2163. [CrossRef]

106. Burke, P.J.; Widnyana, J.; Anjum, Z.; Aisbett, E.; Resosudarmo, B.; Baldwin, K.G. Overcoming Barriers to Solar and Wind Energy Adoption in Two Asian Giants: India and Indonesia. Energy Policy 2019, 132, 1216-1228. [CrossRef]

107. Sindhu, S.; Nehra, V.; Luthra, S. Identification and Analysis of Barriers in Implementation of Solar Energy in Indian Rural Sector Using Integrated ISM and Fuzzy MICMAC Approach. Renew. Sustain. Energy Rev. 2016, 62, 70-88. [CrossRef]

108. Yadav, P.; Davies, P.J.; Khan, S. Breaking into the photovoltaic energy transition for rural and remote communities: Challenging the impact of awareness norms and subsidy schemes. Clean Technol. Environ. Policy 2020, 22, 817-834. [CrossRef]

109. Gautam, A.; Shankar, R.; Vrat, P. End-of-life solar photovoltaic e-waste assessment in India: A step towards a circular economy. Sustain. Prod. Consum. 2021, 26, 65-77. [CrossRef]

110. Guo, Q.; Kluse, C. A framework of photovoltaics recycling facility location optimization. Sustain. Prod. Consum. 2020, 23, 105-110. [CrossRef]

111. Arora, N.; Bhattacharjya, S.; Bakshi, S.; Anand, M.; Dasgupta, D.; Gupta, A.; Prasad, N.S.; Nanda, N. Greening the Solar PV Value Chain; European Union-Resource Efficiency Initiative (EU-REI) Project: New Delhi, India, 2018.

112. Dos Santos, S.A.A.; Torres, J.P.N.; Fernandes, C.A.F.; Lameirinhas, R.A.M. The impact of aging of solar cells on the performance of photovoltaic panels. Energy Convers. Manag. X 2021, 10, 100082. [CrossRef]

113. Jordan, D.C.; Kurtz, S.R. Photovoltaic Degradation Rates-an Analytical Review. Prog. Photovolt. Res. Appl. 2013, $21,12-29$. [CrossRef]

114. Sastry, O.; Saurabh, S.; Shil, S.; Pant, P.; Kumar, R.; Kumar, A.; Bandopadhyay, B. Performance analysis of field exposed single crystalline silicon modules. Sol. Energy Mater. Sol. Cells 2010, 94, 1463-1468. [CrossRef]

115. Raina, G.; Sinha, S. Outlook on the Indian scenario of solar energy strategies: Policies and challenges. Energy Strat. Rev. 2019, 24, 331-341. [CrossRef]

116. Shukla, A.K.; Sudhakar, K.; Baredar, P.; Mamat, R. Solar PV and BIPV system: Barrier, challenges and policy recommendation in India. Renew. Sustain. Energy Rev. 2018, 82, 3314-3322. [CrossRef]

117. Deshwal, D.; Sangwan, P.; Dahiya, N. How will COVID-19 impact renewable energy in India? Exploring challenges, lessons and emerging opportunities. Energy Res. Soc. Sci. 2021, 77, 102097. [CrossRef] 
118. Lal, R. Integrating Animal Husbandry With Crops and Trees. Front. Sustain. Food Syst. 2020, 4, 113. [CrossRef]

119. Stevens, C.J. Nitrogen in the Environment. Science 2019, 363, 578-580. [CrossRef] [PubMed]

120. Zhang, C.; Ju, X.; Powlson, D.; Oenema, O.; Smith, P. Nitrogen Surplus Benchmarks for Controlling N Pollution in the Main Cropping Systems of China. Environ. Sci. Technol. 2019, 53, 6678-6687. [CrossRef]

121. Houlton, B.Z.; Almaraz, M.; Aneja, V.; Austin, A.T.; Bai, E.; Cassman, K.G.; Compton, J.E.; Davidson, E.A.; Erisman, J.W.; Galloway, J.N.; et al. A World of Cobenefits: Solving the Global Nitrogen Challenge. Earth's Futur. 2019, 7, 865-872. [CrossRef]

122. Reay, D. Climate-Smart Milk. In Climate-Smart Food; Reay, D., Ed.; Springer International Publishing: Cham, Switzerland, 2019; pp. 49-66. ISBN 978-3-030-18206-9.

123. Schulze, E.D.; CarboEurope the CarboEurope Team; Luyssaert, S.; Ciais, P.; Freibauer, A.; Janssens, I.A.; Soussana, J.F.; Smith, P.; Grace, J.; Levin, I.; et al. Importance of methane and nitrous oxide for Europe's terrestrial greenhouse-gas balance. Nat. Geosci. 2009, 2, 842-850. [CrossRef]

124. Crime Index for Country 2016. Available online: https://ncrb.gov.in/en/crime-india (accessed on 31 July 2021).

125. Ahmad, F.; Foundation, M.V.E.A.N.H.; Uddin, M.; Goparaju, L. Role of Geospatial technology in Crime Mapping: A case study of Jharkhand state of India. Am. J. Geogr. Res. Rev. 2018, 2, 1-11. [CrossRef]

126. Iyer, L.; Topalova, P.B. Poverty and Crime: Evidence from Rainfall and Trade Shocks in India; Social Science Research Network: Rochester, NY, USA, 2014.

127. Palit, D.; Sarangi, G.K.; Krithika, P.R. Energising Rural India Using Distributed Generation: The Case of Solar Mini-Grids in Chhattisgarh State, India. In Mini-Grids for Rural Electrification of Developing Countries; Springer: Singapore, 2014 ; pp. 313-342.

128. Mindú, A.J.; Capece, J.A.; Araújo, R.E.; Oliveira, A.C. Feasibility of Utilizing Photovoltaics for Irrigation Purposes in Moamba, Mozambique. Sustainability 2021, 13, 10998. [CrossRef]

129. Trommsdorff, M. An Economic Analysis of Agrophotovoltaics: Opportunities, Risks and Strategies towards a More Efficient Land Use; The Constitutional Economics Network Working Papers; University of Freiburg: Freiburg, Germany, 2016.

130. Bahinipati, C.S.; Patnaik, U. The damages from climatic extremes in India: Do disaster-specific and generic adaptation measures matter? Environ. Econ. Policy Stud. 2014, 17, 157-177. [CrossRef]

131. Bahinipati, C.S. Determinants of Farm-Level Adaptation Diversity to Cyclone and Flood: Insights from a Farm Household-Level Survey in Eastern India. Water Policy 2015, 17, 742-761. [CrossRef]

132. Bahinipati, C.S. Assessment of Vulnerability to Cyclones and Floods in Odisha, India: A District-Level Analysis. Curr. Sci. 2014, 107, 1997-2007.

133. Singh, G. Crop Insurance in India; Indian Institute of Management Ahmedabad: Ahmedabad, India, 2010.

134. Mirza, M.M.Q. Climate Change, Flooding in South Asia and Implications. Reg. Environ. Chang. 2011, 11, 95-107. [CrossRef]

135. Mirza, M.M.Q. Climate change and extreme weather events: Can developing countries adapt? Clim. Policy 2003, 3, 233-248. [CrossRef]

136. Bouwer, L.M.; Crompton, R.P.; Faust, E.; Höppe, P.; Pielke, R.A. Confronting Disaster Losses. Science 2007, 318, 753. [CrossRef]

137. Botzen, W.J.W.; Bergh, J.C.J.M.V.D. Managing natural disaster risks in a changing climate. Environ. Hazards 2009, 8, 209-225. [CrossRef]

138. Weckend, S.; Wade, A.; Heath, G.A. End of Life Management: Solar Photovoltaic Panels; National Renewable Energy Lab. (NREL): Golden, CO, USA, 2016.

139. Alam, M.K.; Khan, F.H.; Johnson, J.; Flicker, J. PV Faults: Overview, Modeling, Prevention and Detection Techniques. In Proceedings of the 2013 IEEE 14th Workshop on Control and Modeling for Power Electronics (COMPEL), Salt Lake City, UT, USA, 23-26 June 2013; IEEE: New Jersey, NJ, USA, 2013; pp. 1-7.

140. Wu, Z.; Hu, Y.; Wen, J.X.; Zhou, F.; Ye, X. A Review for Solar Panel Fire Accident Prevention in Large-Scale PV Applications. IEEE Access 2020, 8, 132466-132480. [CrossRef]

141. AbdulMawjood, K.; Refaat, S.S.; Morsi, W.G. Detection and Prediction of Faults in Photovoltaic Arrays: A Review. In Proceedings of the 2018 IEEE 12th International Conference on Compatibility, Power Electronics and Power Engineering (CPE-POWERENG 2018), Doha, Qatar, 10-12 April 2018; pp. 1-8.

142. Mukherjee, S.; Pal, P. On Improving Awareness about Crop Insurance in India. Rev. Agrar. Stud. 2019, 9, 46-68.

143. Gupta, N.; Pradhan, S.; Jain, A.; Patel, N. Sustainable Agriculture in India 2021-What We Know and How to Scale Up; Council on Energy, Environment and Water: New Delhi, India, 2021.

144. Singh, A. Conjunctive Use of Water Resources for Sustainable Irrigated Agriculture. J. Hydrol. 2014, 519, 1688-1697. [CrossRef]

145. Kumar, D.S.; Palanisami, K. Impact of Drip Irrigation on Farming System: Evidence from Southern India. Agric. Econ. Res. Rev. 2010, 23, 265-272.

146. Narayanamoorthy, A. Drip Irrigation in India: Can It Solve Water Scarcity? Water Policy 2004, 6, 117-130. [CrossRef]

147. Polak, P.; Nanes, B.; Adhikari, D. A Low Cost Drip Irrigation System for Small Farmers in Developing Countries 1. JAWRA J. Am. Water Resour. Assoc. 1997, 33, 119-124. [CrossRef]

148. Sivanappan, R.K. Rain Water Harvesting, Conservation and Management Strategies for Urban and Rural Sectors. In Proceedings of the National Seminar on Rainwater Harvesting and Water Management, Nagpur, India, 11-12 November 2006; Volume 11, p. 1.

149. Chander, H.; Kumar, G. Rain-Water Harvesting Structures as an Alternative Water Resource under Rain-Fed Conditions of District Hamirpur, Himachal Pradesh, India. CPUH-Res. J. 2018, 3, 226-233. 
150. Krishna, R.S.; Mishra, J.; Ighalo, J.O. Rising Demand for Rain Water Harvesting System in the World: A Case Study of Joda Town, India. World Sci. News 2020, 146, 47-59.

151. Stomph, T.; Dordas, C.; Baranger, A.; de Rijk, J.; Dong, B.; Evers, J.; Gu, C.; Li, L.; Simon, J.; Jensen, E.S.; et al. Chapter One-Designing Intercrops for High Yield, Yield Stability and Efficient Use of Resources: Are There Principles? In Advances in Agronomy; Sparks, D.L., Ed.; Academic Press: Cambridge, MA, USA, 2020; Volume 160, pp. 1-50.

152. Ram, K.; Meena, R.S. Evaluation of Pearl Millet and Mungbean Intercropping Systems in Arid Region of Rajasthan (India). Bangladesh J. Bot. 2014, 43, 367-370. [CrossRef]

153. Banik, P.; Sharma, R.C. Yield and Resource Utilization Efficiency in Baby Corn-Legume-Intercropping System in the Eastern Plateau of India. J. Sustain. Agric. 2009, 33, 379-395. [CrossRef]

154. Pandey, D.N. Multifunctional Agroforestry Systems in India. Curr. Sci. 2007, 92, 455-463.

155. Chandrashekar, H.M. Changing Scenario of Organic Farming in India: An Overview. INGOJ 2010, 5, 034-039. [CrossRef]

156. Mondal, P.; Basu, M.; Bhadoria, P.B.S. Critical Review of Precision Agriculture Technologies and Its Scope of Adoption in India. J. Exp. Agric. Int. 2011, 49-68. [CrossRef]

157. Mondal, P.; Basu, M. Adoption of Precision Agriculture Technologies in India and in Some Developing Countries: Scope, Present Status and Strategies. Prog. Nat. Sci. 2009, 19, 659-666. [CrossRef]

158. Bongiovanni, R.; Lowenberg-Deboer, J. Precision Agriculture and Sustainability. Precis. Agric. 2004, 5, 359-387. [CrossRef]

159. Das, S.; Chatterjee, A.; Pal, T.K. Organic Farming in India: A Vision towards a Healthy Nation. Food Qual. Saf. 2020, 4, 69-76. [CrossRef]

160. Duran, S.; Atasu, A.; Van Wassenhove, L.N. Cleaning after Solar Panels: A Circular Outlook. 2021. Available online: https: / / ssrn.com/abstract=3860571 (accessed on 31 July 2021).

161. Ghosh, S.; Yadav, R. Future of Photovoltaic Technologies: A Comprehensive Review. Sustain. Energy Technol. Assess. 2021, 47, 101410. [CrossRef]

162. Green, M.A.; Emery, K.; Hishikawa, Y.; Warta, W.; Dunlop, E.D. Solar Cell Efficiency Tables (Version 38). Prog. Photovolt. Res. Appl. 2011, 19, 565-572. [CrossRef]

163. Green, M.; Dunlop, E.; Hohl-Ebinger, J.; Yoshita, M.; Kopidakis, N.; Hao, X. Solar Cell Efficiency Tables (Version 57). Prog. Photovolt. Res. Appl. 2021, 29,3-15. [CrossRef]

164. Mahto, R.V.; Sharma, D.K.; Xavier, D.X.; Raghavan, R. Improving Performance of Photovoltaic Panel by Reconfigurability in Partial Shading Condition. JPE 2020, 10, 042004. [CrossRef]

165. AL-Rousan, N.; Isa, N.A.M.; Desa, M.K.M. Advances in Solar Photovoltaic Tracking Systems: A Review. Renew. Sustain. Energy Rev. 2018, 82, 2548-2569. [CrossRef]

166. Awasthi, A.; Shukla, A.K.; SR, M.M.; Dondariya, C.; Shukla, K.N.; Porwal, D.; Richhariya, G. Review on Sun Tracking Technology in Solar PV System. Energy Rep. 2020, 6, 392-405. [CrossRef]

167. Majaw, T.; Deka, R.; Roy, S.; Goswami, B. Solar Charge Controllers Using MPPT and PWM: A Review. ADBU J. Electr. Electron. Eng. (AJEEE) 2018, 2, 1-4.

168. Seyedmahmoudian, M.; Horan, B.; Soon, T.K.; Rahmani, R.; Oo, A.M.T.; Mekhilef, S.; Stojcevski, A. State of the Art Artificial Intelligence-Based MPPT Techniques for Mitigating Partial Shading Effects on PV Systems-A Review. Renew. Sustain. Energy Rev. 2016, 64, 435-455. [CrossRef]

169. Singh, O.; Gupta, S.K. A Review on Recent Mppt Techniques for Photovoltaic System. In Proceedings of the 2018 IEEMA Engineer Infinite Conference (eTechNxT), New Delhi, India, 13-14 March 2018; IEEE: New Jersey, NJ, USA, 2018; pp. 1-6.

170. Nelson, A.R.L.E.; Ravichandran, K.; Antony, U. The Impact of the Green Revolution on Indigenous Crops of India. J. Ethn. Foods 2019, 6, 1-10.

171. Candler, W.; Kumar, N. India: The Dairy Revolution: The Impact of Dairy Development in India and the World Bank's Contribution; World Bank Publications: Washington, DC, USA, 1998.

172. Rajat, A.; Hiwase, A.; Singh, C.P.; Ezhilan, O.; Sataluri, P.; Thejas, N.; Vidyabharathi. 20 Years of India's Telecom Revolution; लोकनीति। Lokniti: New Delhi, India, 2020.

173. Nam, C.W.; Steinhoff, P. The 'Make in India' Initiative. In Proceedings of the CESifo Forum, Ifo Institute, Munich, Germany, 20-21 April 2018; Volume 19, pp. 44-45.

174. Soil Health Card. Available online: https://www.soilhealth.dac.gov.in/ (accessed on 19 October 2021).

175. Tawalbeh, M.; Al-Othman, A.; Kafiah, F.; Abdelsalam, E.; Almomani, F.; Alkasrawi, M. Environmental Impacts of Solar Photovoltaic Systems: A Critical Review of Recent Progress and Future Outlook. Sci. Total Environ. 2020, 759, 143528. [CrossRef] [PubMed]

176. Palit, D.; Bandyopadhyay, K.R. Rural Electricity Access in India in Retrospect: A Critical Rumination. Energy Policy 2017, 109, 109-120. [CrossRef]

177. Gaur, U. Loan Waiver Scheme and Indian Agriculture; CCS Working Paper; Centre for Civil Society: New Delhi, India, 2008.

178. Jha, S.; Mohapatra, A.K.; Lodha, S.S. Political Economy of Farm Loan Waivers in India. FIIB Bus. Rev. 2019, 8, 88-93. [CrossRef]

179. Raj, D.S.; Prabu, E. Agricultural Loan Waiver: A Case Study of Tamil Nadu's Scheme. RBI Occas. Pap. 2018, 39. Available online: https://www.researchgate.net/publication/330104596_Agricultural_Loan_Waiver_A_Case_Study_of_Tamil_Nadu\ T1 \textquoterights_Scheme (accessed on 31 July 2021). 
180. Ramakumar, R. India's Agricultural Debt Waiver Scheme, 2008. Rev. Agrar. Stud. 2013, 3. Available online: http://ras.org.in/ indias_agricultural_debt_waiver_scheme_2008 (accessed on 31 July 2021).

181. Kumari, P. Agricultural Loan Waiver in India: An Analysis. PalArch's J. Archaeol. Egypt/Egyptol. 2021, 18, 2917-2928. 